DOE/RL-97-28 REV.O

UC- 630

\title{
Radioactive Air Emissions \\ Notice of Construction \\ Fuel Removal for 105-KW Basin
}

Date Published

April 1997

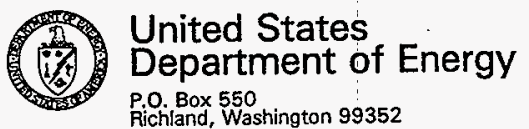

Approved for Public Release 


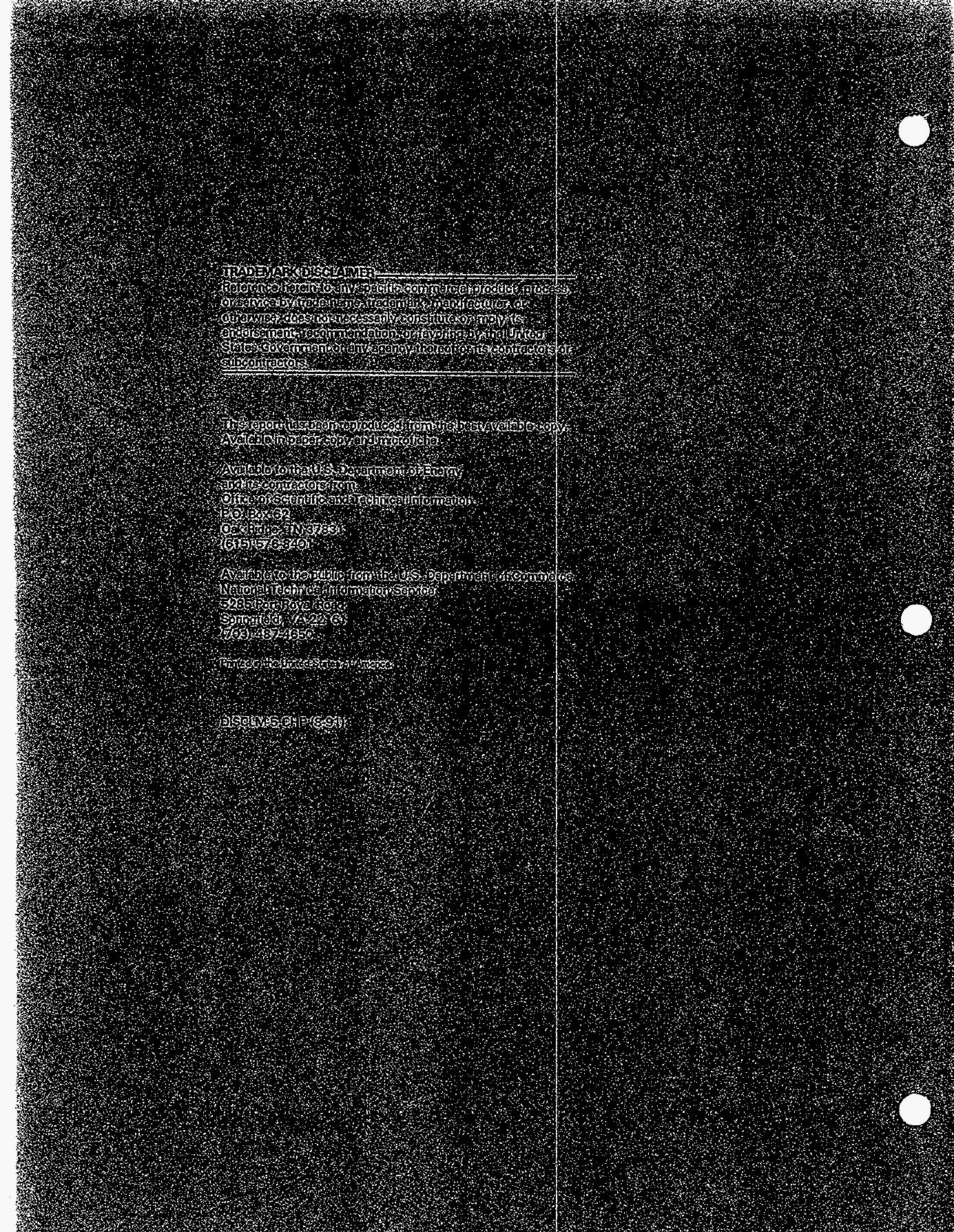




\section{$05 / 29 / 97 \quad 11: 55 \quad 25093762816$ \\ REG SUPPORT \\ IRR grage, 1003}

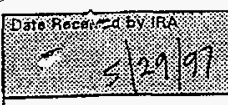

\begin{tabular}{|c|c|}
\hline & \\
\hline A. Information Category \\
\hline Speech or Presentation \\
$\square$ full Paper \\
$\square$ Soummary \\
$\square$ Multimedia Prosentation \\
$\square$ Abstract \\
$\square$ Software \\
$\square$ Visual Aid \\
\hline$\square$ othar Notice of Construc \\
\hline
\end{tabular}

\section{INFORMATION RELEASE REQUEST - (Long Form)}

(GRAY SHADED AREAS NOT TO BE FILLED IN BY INITIATOR)

1. COMPLETE THIS SECTION FOR ALI. DOCUMENTS

B. Document ID Number tinclude rev., vol., otc.)

DOE/RL-97-28, REV. OXfok

C. List attachtnents (i.e., copyright peemission, copyright transfer)

None

$\mathbb{X}$ othar Notice of Construc

D. Dooument Titla

Radioactive Air Emissions

Notice of Construction

Fuel Removal for 105-KW Bas in

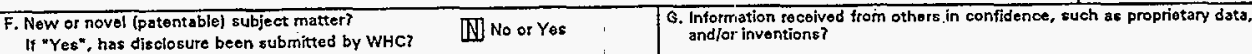
WN No or Yos.
If "Yes", contact WHC General Counsel.
$\square$ No or Yos If "Yos", Disclosure Nols):

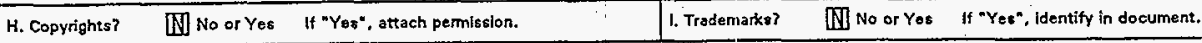
2. COMPLETE THIS SECTION FOR ALL DOCUMENTS REOUIRING SUBMISSION TO OSTI

\begin{tabular}{|l|l|l|l|}
\hline A. Unclassified Category & UC -630 & B. Budget \& Reporting Code & B\&R - \\
\hline & 3. COMPLETE THIS SECTION ONLY FOR A , IOURNAL SUBMISSION \\
\hline
\end{tabular}

A. Tinte of Journal

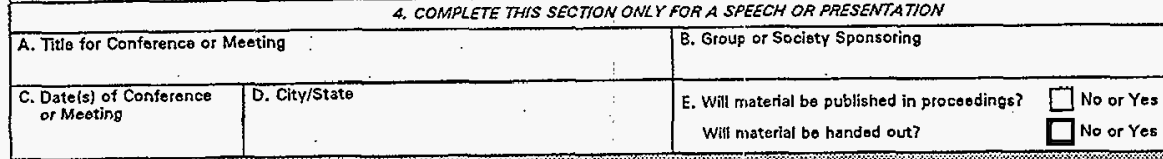

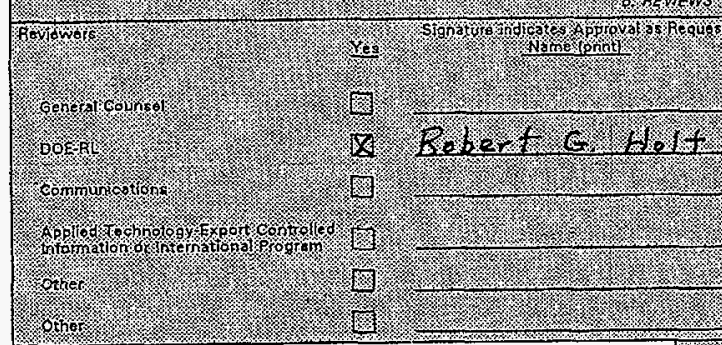

6. Applied Technology Materisi Roferencad
X] No
$\square$ Yea

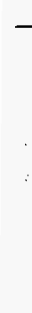

; $5: 2$

\begin{tabular}{|c|c|c|}
\hline & {$[X]$ No } & DYes \\
\hline 7. Reloaso Lovel & & \\
\hline & X Public & $\square$ Limited Distriburtiọn \\
\hline
\end{tabular}

Lamy Kamberg (Print and Signi)

9, Resporisible Manager

$$
\text { Eripl. Sruager }
$$

Eric Greager:

\section{$2-28-97$}

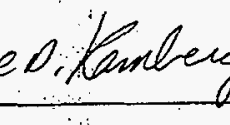

$$
3 / 3 / 97
$$

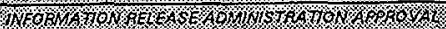

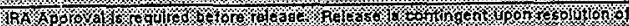

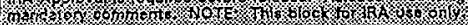
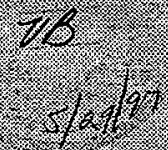
Document ID Number

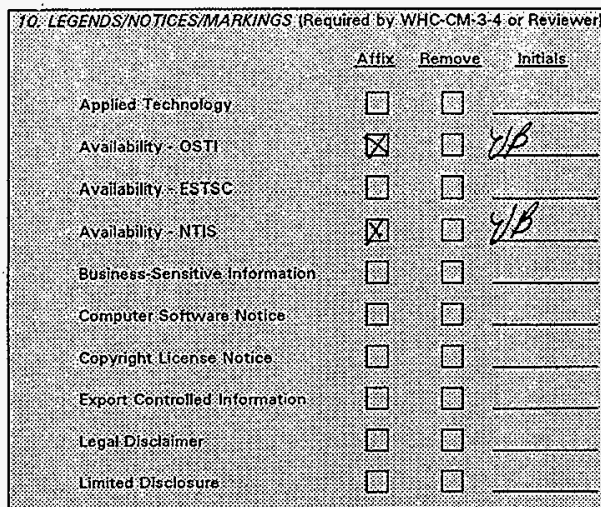

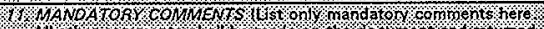

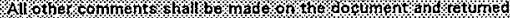
tothowithol

Reviewer indicates applicable markings to be affixed or temoved

Affix peopovo, intitals

offouldovonty

Patentstatus

predectsonal information

Proginimatic Notco

Froprotan ln formation

puposerind vo

Ties 10 issertation

rademark ojsctamor

othet

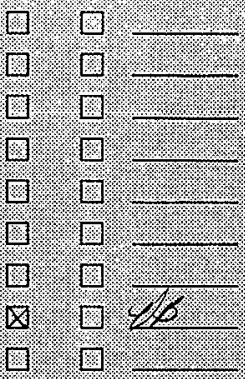

rever w

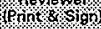

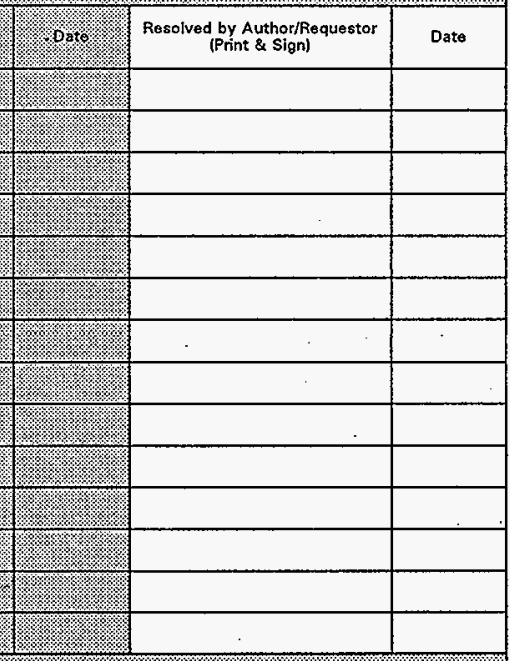



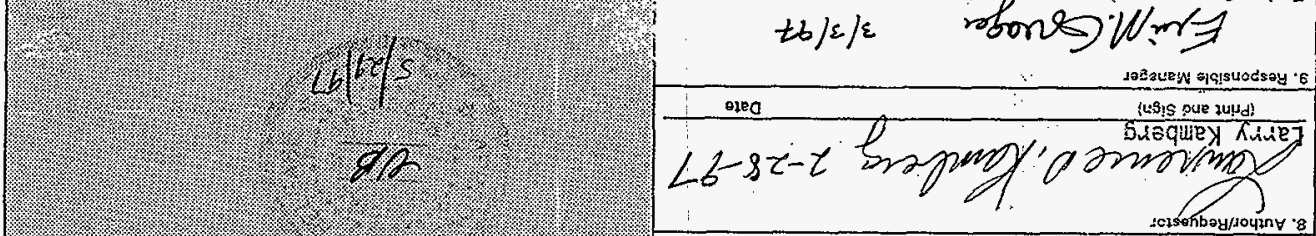

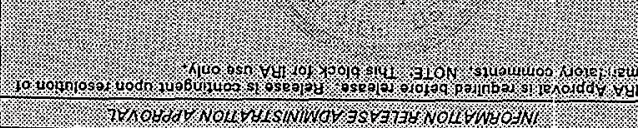

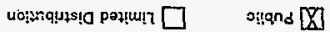

scisonboy/soy?nY : 8

30人 $\square$ ON $[$ X]

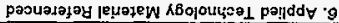

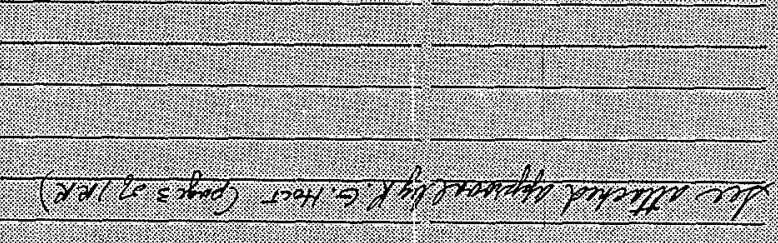

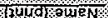

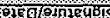

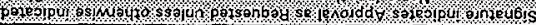

shangu:

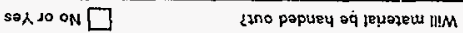

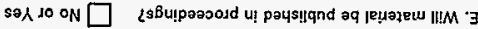

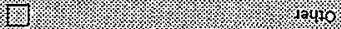

30410

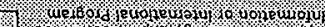

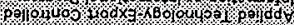

田

S10010010100100

18001

105010010000

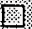

$5 \mathrm{sor}$

stonotrat

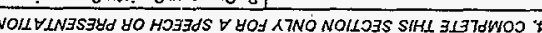

Bบ!1วอW

peunor to apt.

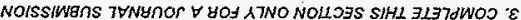

\begin{tabular}{|c|c|c|}
\hline-488 & apos Bu!poday 8 jaBpng ' $\mathrm{g}$ & $\cos 20-\partial n ! 0 \varepsilon 9-3 n$ \\
\hline
\end{tabular}

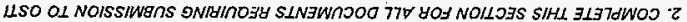

\begin{tabular}{|c|c|c|c|c|c|c|}
\hline 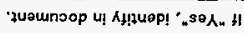 & sa人 do on $[\mathrm{N}]$ & ¿sжнеuюpedi I & & 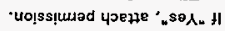 & se人 10 on [N] & ¿\$4b!ykdoo $\mathrm{H}$ \\
\hline${ }^{\dagger} j$ & & sex so on $\mathbb{N}$ & & $:(8$ & s! & sardo \\
\hline
\end{tabular}

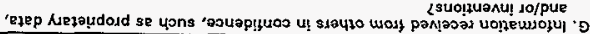

sos 10 oN $[\mathrm{N}]$

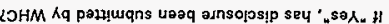

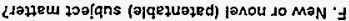

$\exists N S$

u!seg MX-sol lof lenomay land uo!̣วnlq5U0 to $ә 0 ! 70 \mathrm{~N}$

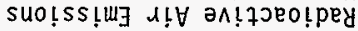

วUON

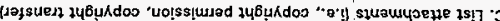

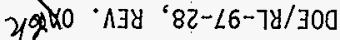

["oza " "

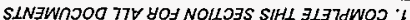

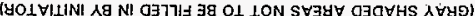

(usof 6uo7) - IS हदा सिक्या
J souro $[X]$

P!ช fensin

zoensq $\square$ Newuns

jaded lng Lolnejuased do yoards

Nobazej vo!newroju! $v$ ap!มष jeunor

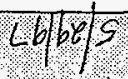

V 1 A $0,0,000 \mathrm{~g}$ ग1e0

-

Se.n. 


\section{CONTENTS}

METRIC CONVERSION CHART .................. vii

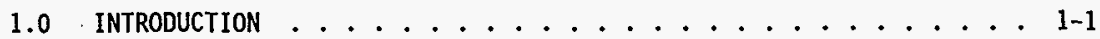

2.0 FACILITY LOCATION (Requirement 1) ................. 2-1

3.0 RESPONSIBLE MANAGER (Requirement 2) ................ 3-

4.0 TYPE OF PROPOSED ACTION (Requirenent 3) .............. 4-1

5.0 STATE ENVIRONMENTAL POLICY ACT kequirement 4) ........ 5 . . . .

6.0 PROCESS DESCRIPTION (Requirements 5 and 7 ) ........... $6-1$ 6.1 EQUIPMENT AND PROCESS DESCRIPTIONS .......... $6-9$

6.1 .1 Fuel Retrieval System . . . . . . . 6-9

6.1.1.1 Fuel Retrieval System Equipment

Description ......... . 6- 6-9

6.1.1.2 Fuel Retrieval System Equipment

6.1.1.3 Fuel Retrieval System Équipment

Maintenance . . . . 6-16

6.1.2 Multi-Canister Overpack/Cask Loadout Operations

Overview ........... 6-16

6.1.2.1 Muiti-Canister Overpack . . . . . 6-16

6.1 .2 .2 Cask ............. 6-16

6.1.2.3 Immersion Pail .......... 6-19

6.1.2.4 Conveyance Vehicle ........ 6-19

6.1.2.5 Multi-Canister Overpack Loading System . . 6-19

6.1.3 Integrated Water Treatment System Overview ....6-23

6.1.3.1 Integrated Water Treatment System . . . 6-24

6.1 .3 .2 Water Addition ......... 6-25

6.1.3.3 Excess Water Removed From the Basin... 6-25

6.1.3.4 Integrated Water Treatment System

6.1.3.5 Integrated Water Treatment System

Maintenance ......... 6-26

6.1 .4 Sludge Relocation . . . . . . . . . . 6-26

6.2 FACILITY MODIFICATIONS ............ . . . 6-27

6.2.1 General Construction Activities . . . . . . . 6-27

6.2 .2 Fuel Retrieval system . . . . . . . . . 6-28

6.2.3 Multi-Canister Overpack/Cask Loadout System . . . . 6-28

6.2.4 Integrated Water Treatment System . . . . . . 6-29

6.2.5 Water Returns to the 105-KW Basin from Cold Vacuum

Drying Facility ........... 6- 6-30

6.3 DEBRIS REMOVAL DESCRIPTION .......... . 6-30

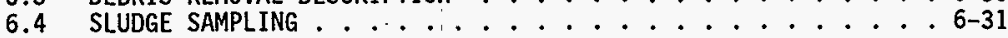


7.0 ANNUAL POSSESSION QUANTITY AND PHYSICAL FORM

(Requi rements $8,10,11$, and 12) . . . . . . . . . . . . . . . 7-1

7.1 SOURCE TERM DESCRIPTION . . . . . . . . . . . . . . . $7-1$

7.1 .1 Fuel Elements . . . . . . . . . . . . . . 7-2

7.1 .2 Basin Water . . . . . . . . . . . . 7-2

7.1 .3 Sludge ................... 7-2

7.1 .4 Surface Contamination ............ 7-4

7.1.5 Multi-Canister Overpack Source Term . . . . . . 7-5

7.1.6 Multi-Canister Overpack Particulate . . . . . . . 7-5

7.1 .7 Gases ................. 7-5

7.1.8 Source Term for Above Hater Work . . . . . . . . 7-6

7.2 ANNUAL POSSESSION QUANTITY, PHYSICAL FORM, RELEASE FORM,

AND CHEMICAL FORM .................. 7-7

8.0 CONTROL SYSTEM (Requirement 6) .................... 8-1

8.1 CONTROL EQUIPMENT .................. 8-1

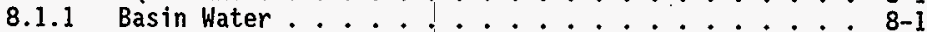

8.1.2 Existing Water Treatment .......... 8-1

8.1.3 Integrated Water Treatinent System . . . . . . . 8-1

8.2 CONTROLS FOR ABOVE WATER ACTIVITIES ............ 8-2

8.3 CONTROL EQUIPMENT EFFICIENCIES ...........

8.4 INTEGRATED WATER TREATMENT SYSTEM OPERATIONAL CONTROLS $. . .8-3$

9.0 MONITORING SYSTEM (Requirement 9) .................. 9-1

10.0 RELEASE RATES (Requirement 13) .................. . . 10-1 10.1 PROJECTED EMISSIONS WITHOUT ABATEMENT CONTROLS IN PLACE

(POTENTIAL TO EMIT) ................ . . 10-1

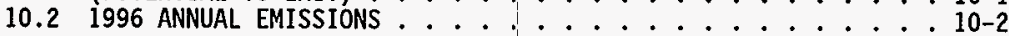

11.0 OFFSITE IMPACT (Requirement 14 and 15 ) . . . . . . . . . . . . 11-1

12.0 FACILITY LIFETIME (Requirement 17) . . . . . . . . . ...... 12-1

13.0 TECHNOLOGY STANDARDS (Requirement 18)................. 13-1

14.0 REFERENCES . . . . . . . . . . . . . . . . . . . 14-1

APPENDIX

A DISCUSSION OF AS LOW AS REASONABLY AC:HIEVABLE CONTROL

TECHNOLOGY 


\section{FIGURES}

2-1. Location of the 100-K Area within the Hanford Site ...... 2-2

2-2. Location of 105-KW and 105-KE Basins within the 100-K Area . . . . 2-3

6-1. Fuel Retrieval System General System Layout .......... 6-3

$6-2$. The Basin Water Level in Relation to the Stored Fuel . . . . 6-5

6-3. Multi-Canister Overpack Fuel Basket ........... 6-7

6-4. Conceptual Schematic of the Fuel Retrieval System Mechanical

Flow...................... 6-11

6-5. Fuel Element with Inner and Outer Elements ........... 6-15

6-6. Multi-Canister Overpack with Mechanical Closure Assembly . . . . . 6-17

6-7. Cask Assembly ................. 6-18

6-8. Immersion Pail Interfaces .............. 6-20

6-9. Cask and Conveyance System .............. 6-21

9-1. Fixed Head Sampler Positions ................ 9-2

9-2. Locations of Near-Field Monitoring Locations . . . . . . . . 9. 9-4

\section{TABLES}

7-1. 105-KW Basin Radionuclide Inventory (Source Term) . . . . . . 7-3

7-2. Radionucl ides in 105-KH Basin Water (October 1, 1996) ..... 7-4

7-3. Estimated Above Water Source Term In $105 \mathrm{~K}$ West Basin ...... 7-6

7-4. Physical Form, Release Form, and Chemical Form . . . . . . . 7-7

8-1. Average Radionuclide Field Measured Maximum Removal Efficiencies

of the 105-KW Basin Water Treatment System Components . . . . 8-2

8-2. Projected Particulate Removal Efficiencies of the 105-KW Basin Water Treatment System Components ........... 8-3

10-1. Projected Unabated Radioactive Air Emissions . . . . . . 10-1

10-2. Radioactive Air Emissions Measured at 105-KW Basin in Calendar Year .................. 10-2

10-3. Good Engineering Judgment Projected Abated Emissions ....... 10-3

10-4. Potential to Emit from Excess Water via Tanker Truck to 200 Area Effluent Treatment Facility . . . . . . . . . 10-6

11-1. Total Effective Dose Equivalent to the Maximally Exposed Individual for the Unabated Emissions ........... 11-1

11-2. Total Effective Dose Equivalent to the Maximally Exposed Individual Using CAP-88 Dose Conversion Factors for Good Engineering Judgment of Abated Emissions . . . . . . . 11-2 
$42 \mathrm{Kpa}$

43

EOC

FRS

MEI

MCO

NOC

PTE

SNF

SPR

HAC

$\mathrm{Ci}$

$c^{\circ}$

$\mathrm{kg}$

MTU

rem

$\mu \mathrm{Ci}$
ALARA

ALARACT

CFR

CVDF

HEPA

HNF

IWTS

IXM

SEPA

TEDE

WDOH

Ci/day

$\mathrm{Ci} / \mathrm{yr}$

mrem

$\mu \mathrm{Ci} / \mathrm{m} \mathrm{T}$

$\mu \mathrm{Ci} / \mathrm{L}$ as low as reasonable ach ievable

as low as reasonably ach jevable control technology

Code of Federal Regulations

Cold Vacuum Drying Facility

equipment operations center

fuel retrieval system

high-efficiency particulate air

Hanford Nuclear Facility

integrated water treatment system

ion exchange module

maximally exposed individual

multi-canister overpack

notice of construction

potential to emit

(Washington) State Environmental Policy Act of 1971 spent nuclear fuel

single pass reactor

total effective dose equivalent

Washington Administrative Code

Washington State Department of Health

curies

curies per day

curies per year

degrees Celsius

kilogram

kilopascal

milliroentgen equivalent man

metric tons of uranium

roentgen equivalent man

microcuries

microcuries per milliliter

microcuries per liter 
12

13

14

15

16

17

\section{METRIC CONVERSION CHIART}

The following conversion chart is provided to the reader as a tool to aid in conversion.

Into metric units Out of metric units

\begin{tabular}{|c|c|c|c|c|c|}
\hline If you know & $\begin{array}{c}\text { Multiply } \\
\text { by }\end{array}$ & To get & If you know & $\begin{array}{c}\text { Multiply } \\
\text { by }\end{array}$ & To get \\
\hline \multicolumn{3}{|c|}{ Length } & \multicolumn{3}{|c|}{ Length } \\
\hline inches & 25.40 & mil] imeters & mil7imeters & 0.0393 & inches \\
\hline inches & 2.54 & centimeters & centimeters & 0.393 & inches \\
\hline feet & 0.3048 & meters & meters & 3.2808 & feet \\
\hline yards & 0.914 & meters & meters & 1.09 & yards \\
\hline miles & 1.609 & kilometers & kilomet:ers & 0.62 & miles \\
\hline \multicolumn{3}{|c|}{ Area } & \multicolumn{3}{|c|}{ Area } \\
\hline $\begin{array}{l}\text { square } \\
\text { inches }\end{array}$ & 6.4516 & $\begin{array}{l}\text { square } \\
\text { centimeters }\end{array}$ & $\begin{array}{l}\text { square } \\
\text { centimeters }\end{array}$ & 0.155 & $\begin{array}{l}\text { square } \\
\text { inches }\end{array}$ \\
\hline square feet & 0.092 & $\begin{array}{l}\text { square } \\
\text { meters }\end{array}$ & $\begin{array}{l}\text { square } \\
\text { meters }\end{array}$ & 10.7639 & $\begin{array}{l}\text { square } \\
\text { feet }\end{array}$ \\
\hline $\begin{array}{l}\text { square } \\
\text { yards }\end{array}$ & 0.836 & $\begin{array}{l}\text { square } \\
\text { meters }\end{array}$ & $\begin{array}{l}\text { square } \\
\text { meters }\end{array}$ & 1.20 & $\begin{array}{l}\text { square } \\
\text { yards }\end{array}$ \\
\hline $\begin{array}{l}\text { square } \\
\text { miles }\end{array}$ & 2.59 & $\begin{array}{l}\text { square } \\
\text { kilometers }\end{array}$ & $\begin{array}{l}\text { square } \\
\text { kilometers }\end{array}$ & 0.39 & $\begin{array}{l}\text { square } \\
\text { miles }\end{array}$ \\
\hline $\begin{array}{l}\text { square } \\
\text { miles }\end{array}$ & 259 & hectares & hectares & 0.00391 & $\begin{array}{l}\text { square } \\
\text { miles }\end{array}$ \\
\hline acres & 0.404 & hectares & hectares & 2.471 & acres \\
\hline \multicolumn{3}{|c|}{ Hass (weight) } & \multicolumn{3}{|c|}{ Mass (weight) } \\
\hline ounces & 28.35 & grams & grams & 0.0352 & ounces \\
\hline pounds & 0.453 & kijograms & kilograms & 2.2046 & pounds \\
\hline short ton & 0.907 & metric ton & metric ton & 1.10 & short ton \\
\hline \multicolumn{3}{|c|}{ Volume } & \multicolumn{3}{|c|}{ Volume } \\
\hline $\begin{array}{l}\text { fluid } \\
\text { ounces }\end{array}$ & 29.57 & milliliters & milliliters & 0.03 & $\begin{array}{l}\text { fluid } \\
\text { ounces }\end{array}$ \\
\hline quarts & 0.95 & liters & liters & 1.057 & quarts \\
\hline gat7ons & 3.79 & Titers & Titers & 0.26 & gallons \\
\hline cubic feet & 0.03 & $\begin{array}{l}\text { cubic } \\
\text { meters }\end{array}$ & $\begin{array}{l}\text { cubic } \\
\text { meters }\end{array}$ & 35.3147 & cubic feet \\
\hline cubic yards & 0.76 & $\begin{array}{l}\text { cubic } \\
\text { meters }\end{array}$ & $\begin{array}{l}\text { cubic } \\
\text { meters }\end{array}$ & 1.308 & $\begin{array}{l}\text { cubic. } \\
\text { yards }\end{array}$ \\
\hline \multicolumn{3}{|c|}{ Temperature } & \multicolumn{3}{|c|}{ Temperature } \\
\hline Fahrenheit & $\begin{array}{l}\text { subtract } \\
32 \text { then } \\
\text { multiply } \\
\text { by } 5 / 9 \text { ths }\end{array}$ & Celsius & Celsius & $\begin{array}{l}\text { multiply } \\
\text { by } \\
9 / 5 \text { ths, } \\
\text { then add } \\
32\end{array}$ & Fahrenheit \\
\hline
\end{tabular}

Source: Engineering Unit Conversions, M. R. Lindeburg, PE., Second Ed., 1990, Professional Publications, Inc., Belmont, California. 
This page intentionally left blank. 


\author{
RADIOACTIVE AIR EMISSIIONS \\ NOTICE OF CONSTRUCTION FOR \\ FUEL REMOVAL AT 105-KH BASIN
}

\title{
1.0 INTRODUCTION
}

This document serves as a notice of construction (NOC), pursuant to the requirements of Washington Administrative Code (WAC) 246-247-060, and as a request for approval to construct, pursuant to 40 Code of Federal Regulations (CFR) 61.96, for the modifications, installation of new equipment, and fuel removal and sludge relocation activities at 105-KW Basin.

The purpose of the activities described in this NOC is to enable the eventual retrieval and transport of the fuel for processing. The fuel retrieval and transport will require an integrated water treatment system (IWTS) for which performance specifications have been developed. These specifications are currently in the procurement process. Following procurement (and before installation of this system and the handling of fuel) design details will be provided to Washington State Department of Health (WDOH).

The 105-K West Reactor (105-KW) and its associated spent nuclear fuel (SNF) storage basin were constructed in the early 1950s and are located on the Hanford Site in the 100-K Area about 1,400 feet from the Columbia River. The 105-KW Basin contains 964 Metric Tons of SNF stored under water in approximately 3800 closed canisters. This SNF has been stored for varying periods of time ranging from 8 to 17 years. The 105-KW Basin is constructed of concrete with an epoxy coating and contains approximately 1.3 million gallons of water with an asphaltic membrane beneath the pool.

Although the 105-KW Basin has not been known to leak, the discharge chute and associated construction joint have been isolated from the rest of the basin by metal isolation barriers. This was a precautionary measure, to mitigate the consequences of a seismic event. The proposed modifications described are scheduled to begin in calendar year 1997. 
DOE/RL-97-28, Rev. 0

04/97

This page intentionaliy left blank. 


\subsection{FACILITY LOCATION (Requirement 1)}

The 105-KW Basin is located within the 105-KW Reactor structure in the 100-K Area of the Hanford Site. The 100-K Area is approximately 25 miles northwest of the city of Richland, Washington. Figure 2-1 shows the location of the 100-K Area within the Hanford Site and Figure 2-2 shows the location of 8 the 105-KW and 105-KE Basins.

There are four roof exhausters in 105-KW Basin. The Washington State Plane Coordinates for these points are as follows:

$\begin{array}{lll}\mathrm{P}-105 \mathrm{KW}-1 & 146445 \mathrm{~N} & 568606 \mathrm{E} \\ \mathrm{P}-105 \mathrm{KW}-2 & 146451 \mathrm{~N} & 568605 \mathrm{E} \\ \mathrm{P}-105 \mathrm{KW}-3 & 146458 \mathrm{~N} & 568627 \mathrm{E} \\ \mathrm{P}-105 \mathrm{KW}-4 & 146465 \mathrm{~N} & 568644 \mathrm{E}\end{array}$

Address: U.S. Department of Energy, Richland Operations Office Hanford Site 100-K Area, 105-KE and -KW Basins Richland, Washington 99352 . 
DOE/RL-97-28, Rev. 0 $04 / 97$

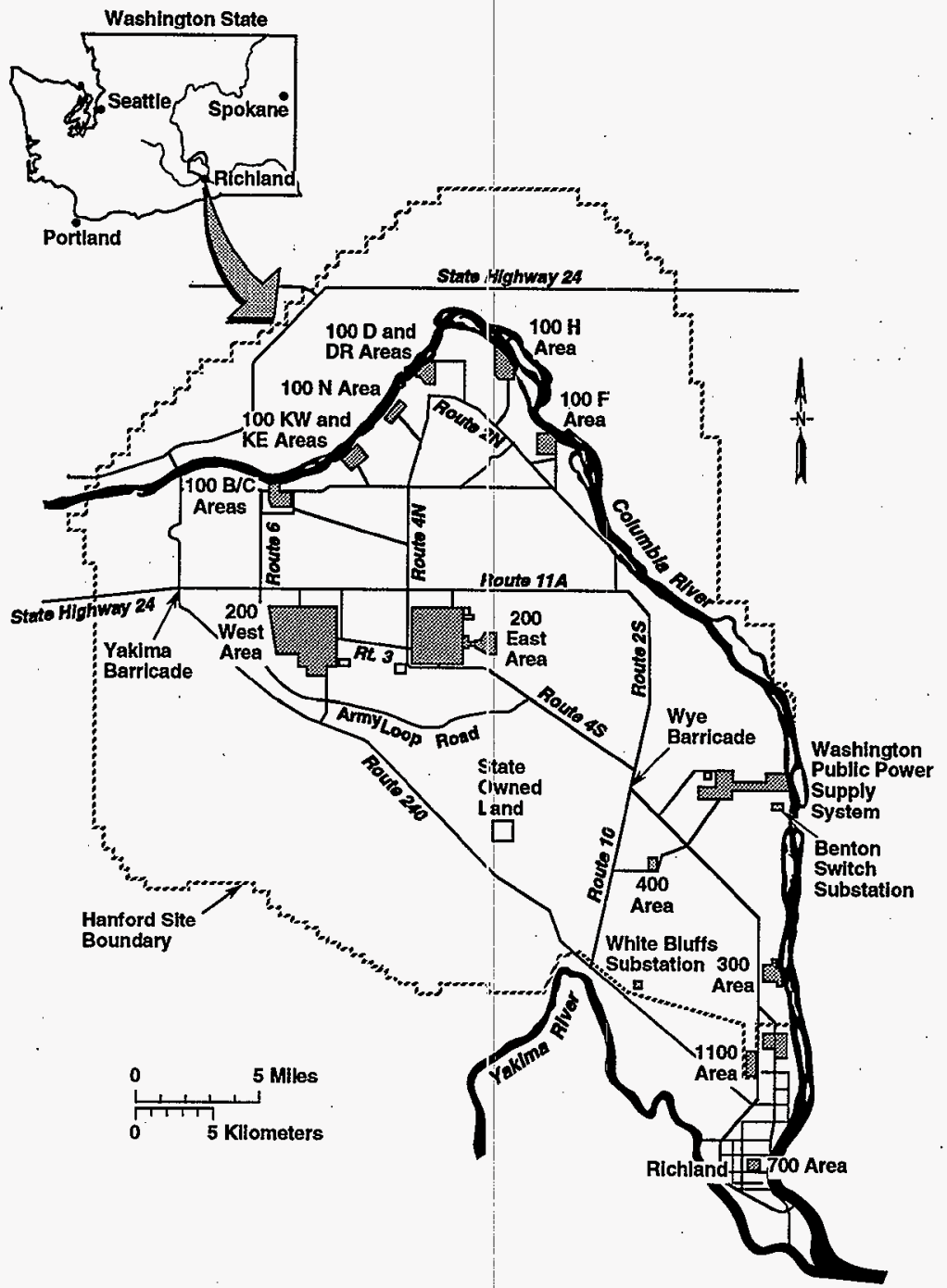

H9702027 1.4

Figure 2-1. Location of the 100-K Area within the Hanford Site. 
DOE/RL-97-28, Rev. 0

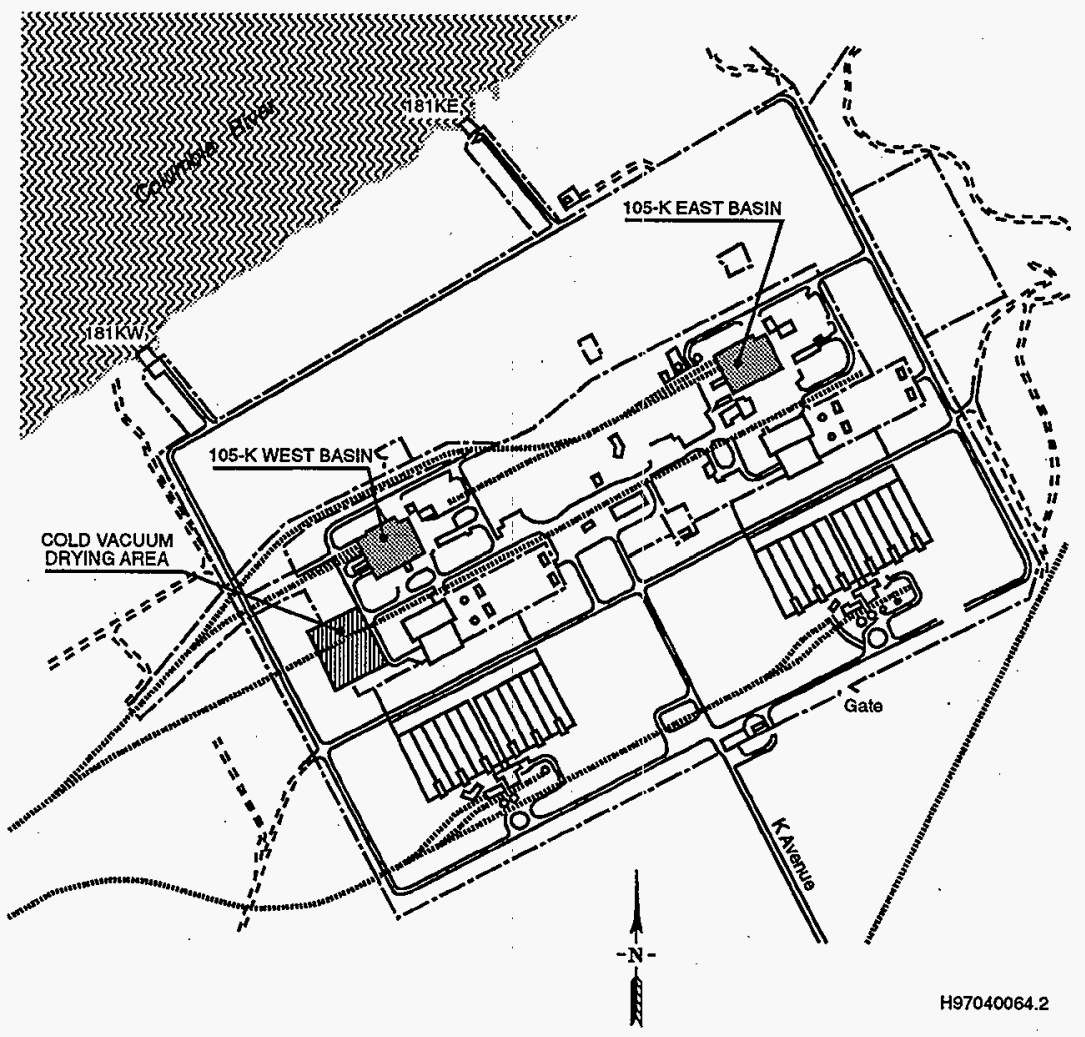

Figure 2-2. Location of 105-KW and 105-KE Basins within the 100-K Area. 
This page intentionalily Teft blank. 


\subsection{RESPONSIBLE MANAGER (Requirement 2)}

The responsible manager's name and address are as follows:

Ms. E. D. Sellers, Division Director

Spent Nuclear Fuels Project Division

U.S. Department of Energy

Richland Operations Office

Mail Stop 57-41

P.0. Box 550

Richl and, WA. 99352

(509) $373-9860$. 
DOE/RL-97-28, Rev. 0

$04 / 97$

This page intentionaliy left blank. 


\subsection{TYPE OF PROPOSED ACTION (Requirement 3)}

The proposed action consists of the installation, operation, and maintenance of fuel removal and sludge relocation equipment, as well as debris removal and minor basin modifications.

This proposed action is not considered a significant modification to the existing facility and operations at the 105-KW Basin in accordance with WAC 246-247-030 (16) and (25). 
DOE/RL-97-28, Rev. 0

04/97

This page intentiona? ly left blank. 


\subsection{STATE ENVIRONMENTAL POLICY ACT (Requirement 4)}

The proposed activity is categorically exenpt from SEPA requirements per 5 WAC 197-11-845(1). 
This page intentionally left blank. 


\subsection{PROCESS DESCRIPTION (Requirements 5 and 7)}

The 105-KW Basin is a rectangular, reinforced concrete basin measuring 125 feet long by 66 feet wide by 21 feet deep with three main storage bays separated by concrete partitions open at each end, two loadout pits, viewing pits, and a discharge chute. Structures for transporting fuel are at the west end where the railroad tracks enter through a large rollup door providing access to the (south) loadout pit. A 30-ton bridge crane is used for lifting casks from the railcar into the loadout pit. Metal grating is suspended over the entire basin, 21 feet above the basin floor ( 5 feet over the nominal water level) to provide a working surface from which operators maneuver the fuel canisters. Canisters are moved by using a hoist and monorail system that runs throughout the 105-KW Basin.

When the basin was refurbished for storage of $\mathbb{N}$ Reactor fuel, an epoxy coating was applied to the basin walls to minimize absorption of radionuclides into the concrete wal1s. Fuel storage operations at the 105- KW Basin have been continuous since 1980. The main storage bay floor is equipped with racks designed to house fuel canisters. The racks maintain the canjsters upright in a fixed geometric array. The existing canisters consist of two cylinders approximately 9 inches in diameter by 26 inches tall, made of aluminum or stainless steel, and joined by trunnions to facilitate handling.

A canister can hold a maximum of $14 \mathrm{~N}$ Reactior fuel elements. Each canister was encapsulated (injected with a corrosion inhibitor then sealed) before storage. A gas trap was provided through the canister 1id to allow the escape of gases and still isolate the contents from the basin water. Studies have shown that for some of the canisters the seals are no longer effective and basin water has entered the canisters (WHC 1.995b).

The water level of the 105-KW Basin is maintained at approximately 16 feet deep to cool the fuel and to provide radiological shielding for personne1. To maintain low concentrations of radionuclides, the water is circulated through a closed-loop water treatment, system. A detailed description of this system is provided in Section 6.1.3.1. The general 1ayout of the fuel retrieval system (FRS) is shown in Figure 6-1 and the basin water level in relation to the stored fuel is shown in Figure 6-2.

A complete description of the 105-KW Basin can be found in the safety analysis report (WHC $1996 \mathrm{~b}$ ) and in technical safety requirements.

This NOC describes activities necessary to remove SNF from the 105-KW Basin and transport the fuel for further processing. Removal and transport of the fuel involves four major program elements as follows: 
D0E/RL-97-28, Rev. 0

$04 / 97$

This page intentionally left blank. 

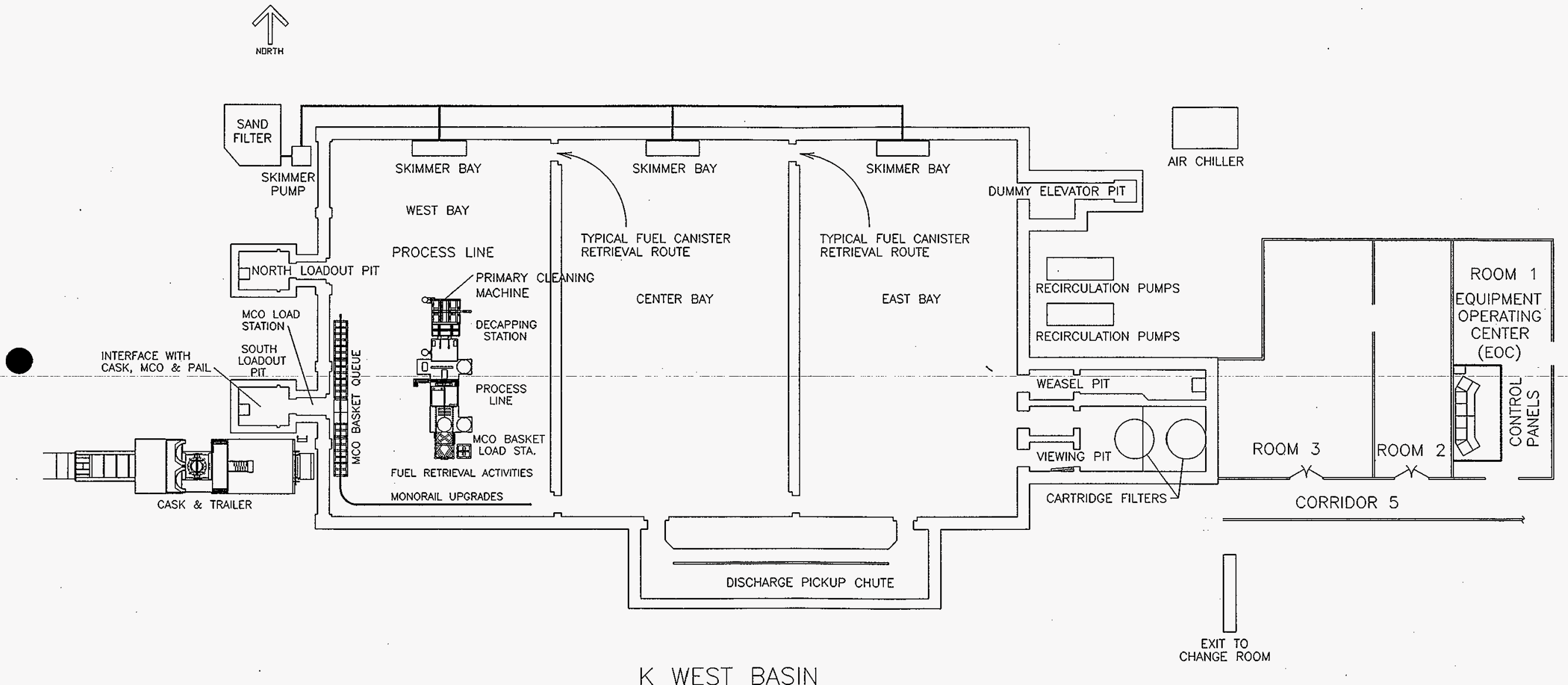

K WEST BASIN

Figure 6-1. Fuel Retrieval System General Layout. 
DOE/RL-97-28, Rev. 0

04/97

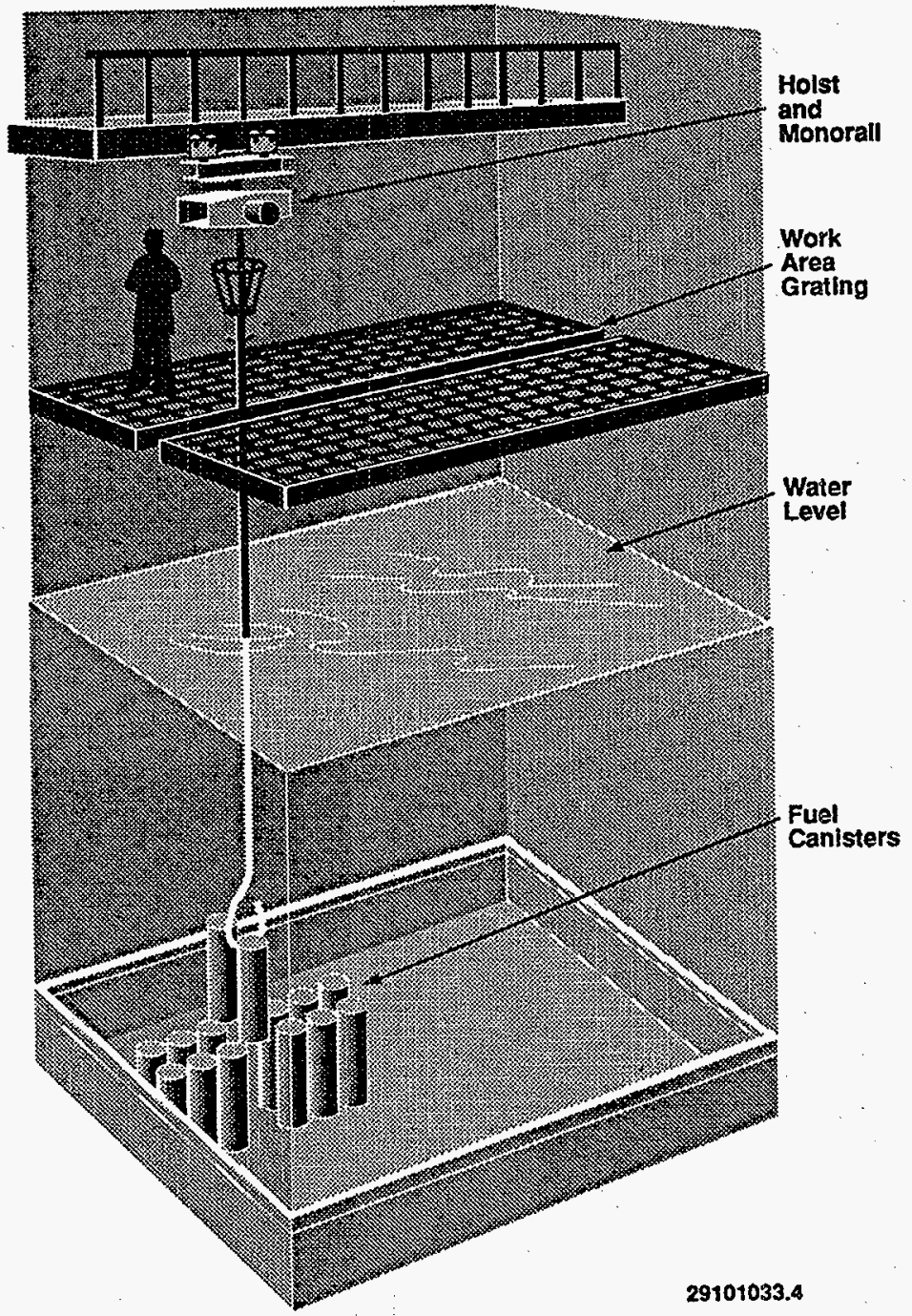

Figure 6-2. The Basin Water Level in Relation to the Stored Fuel. 
- Supporting construction activities necessary to provide the specialized equipment to do the work

- Processing underwater fuel and treating associated water by the integrated water treatment system (IWTS)

- Removing the fuel from the water and transporting the fuel

- Handing of fuel retrieval byproducts including debris and sludge.

The fuel retrieval process will be conifucted underwater. The process will encompass cleaning and repackaging the fuel in multi-canister overpack (MCO) baskets (Figure 6-3). The process has been designed to ensure that as much of the loose oxides as possible are renoved from the fuel before transport. Underwater operations will involve the use of manipulators to handle the fuel, although some (above wateri hoists will be used to handle MCO baskets and canisters. The use of long-handled tongs or similar tools will supplement the manipulators as necessary. The radionuclides dispersed within the water during this process will be collested and treated by the IWTS. The fuel retrieval process cannot be conducted vit thout the IWTS operating, as. necessary, to remove sludge from the work areas.

The fuel, once packaged in MCO baskets and loaded into the MCO, will be removed from the basin by way of a container (MCO and integral cask) that is designed to minimize contamination on the cask as the cask leaves the water. Only the top surface of the MCO will be exposed to the basin water and will be readily decontaminated. The MCO will be closed underwater and seajed within the cask before loading for transport to the CVDF.

The proposed construction activities will involve the installation of uncontaminated (new) equipment in the basin, portions of which witl be placed underwater on the floor of the basin and portions of which will be instalied above water.

During the installation of fuel retrieval system (FRS), IWTS, or MCO/cask loadout equipment, it might be necessary to remove, reconfigure, reinstall, and test such equipment. As low as reasonably achievable (ALARA) methods will be followed to control contamination on this relatively new equipment.

The fuel removal process will result in the generation of approximately 3,800 empty fuel canisters. These canisters and other existing debris will need to be removed from the basin. Any bulk sludge collected by the IWTS will be transported and accumulated into a sludge accumulation area (containers above or below the water or confined area underwater in the basin) for subsequent transfer. The subsequent transfer: will be addressed in a future NOC. 
DOE/RL-97-28, Rev. 0

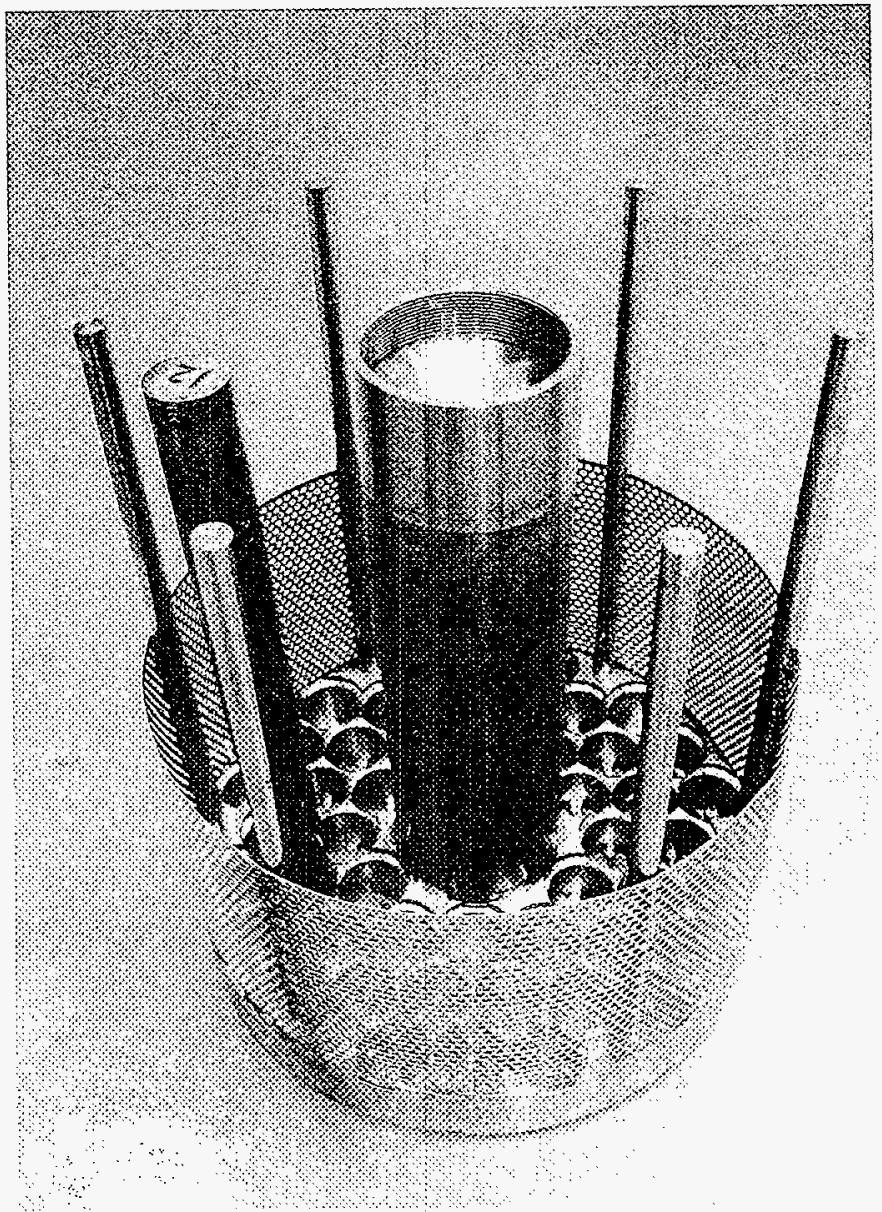

Figure 6-3. Multi-Canister Overpack Fuel Basket: 
This page intentionally left blank. 


\subsection{EQUIPHENT AND PROCESS DESCRIPTIONS}

The equipment will include new systems for the FRS, MCOs, MCO loading, MCO casks, MCO/cask handling, MCO/cask transportation, IWTS, and sludge and debris handling.

Modifications to the existing basin as described in Section 6.2 will be necessary to accommodate these new systems. Equipment descriptions, system operations, and related system maintenance for the new systems are discussed in the following sections.

\subsubsection{Fuel Retrieval System}

The FRS is necessary to enable retrieval of fuel stored in canisters throughout the basin and to prepare the fuel for removal from the basin in a configuration suitable for downstream conditioning processes. A description of the FRS is provided in the following sections.

6.1.1.1 Fuel Retrieval System Equipment Description. Major components of the FRS include the monorail hoists and transfer crane, primary clean machine, process table, manipulators, cameras and lighting, MCO basket queue, equipment. operations center, and stuck fuel equipment. Figure $6 \sim 4$ is a schematic of the FRS mechanical flow.

- Monorail Hoist and Transfer Crane--The 105-KW Basin has an existing monorail and hoist system for the underwater handling of fue? canisters and equipment. This existing monorail system will be modified to include motorized variable speed hoists and a power driven transfer crane capable of moving a fully Toaded MCO basket. The hoists and the flexible transfer crane will be used to move canisters and MCO baskets underwater, and to load empty MCO baskets into the basin.

- Primary Clean Machine--The primary clean machine (refer to Figures 6-1 and $6-5$ ) will be used to facilitate separation of the fuel from the canisters and to remove canister sludge, while minimizing impact on the basin water quality. Primary cleaning will be accomplished via a combination of mechanical agitation and pressure water rinsing. Sludge will be collected into the IWTS and scrap fuel will be accumulated in scrap baskets. Wash water and sludge will be transferred to the IWTS via a hose, pump, and associated piping.

- Process Table--The process table (refer to Figures 6-1 and 6-4) will be the basic support structure for equipment used to inspect and handle the fuel and will consist of a large table with defined areas for fuel handling functions, e.g., disassembly, secondary cleaning, inspection. 
DOE/RL-97-28, Rev. 0

04/97

This page intentionally left blank. 

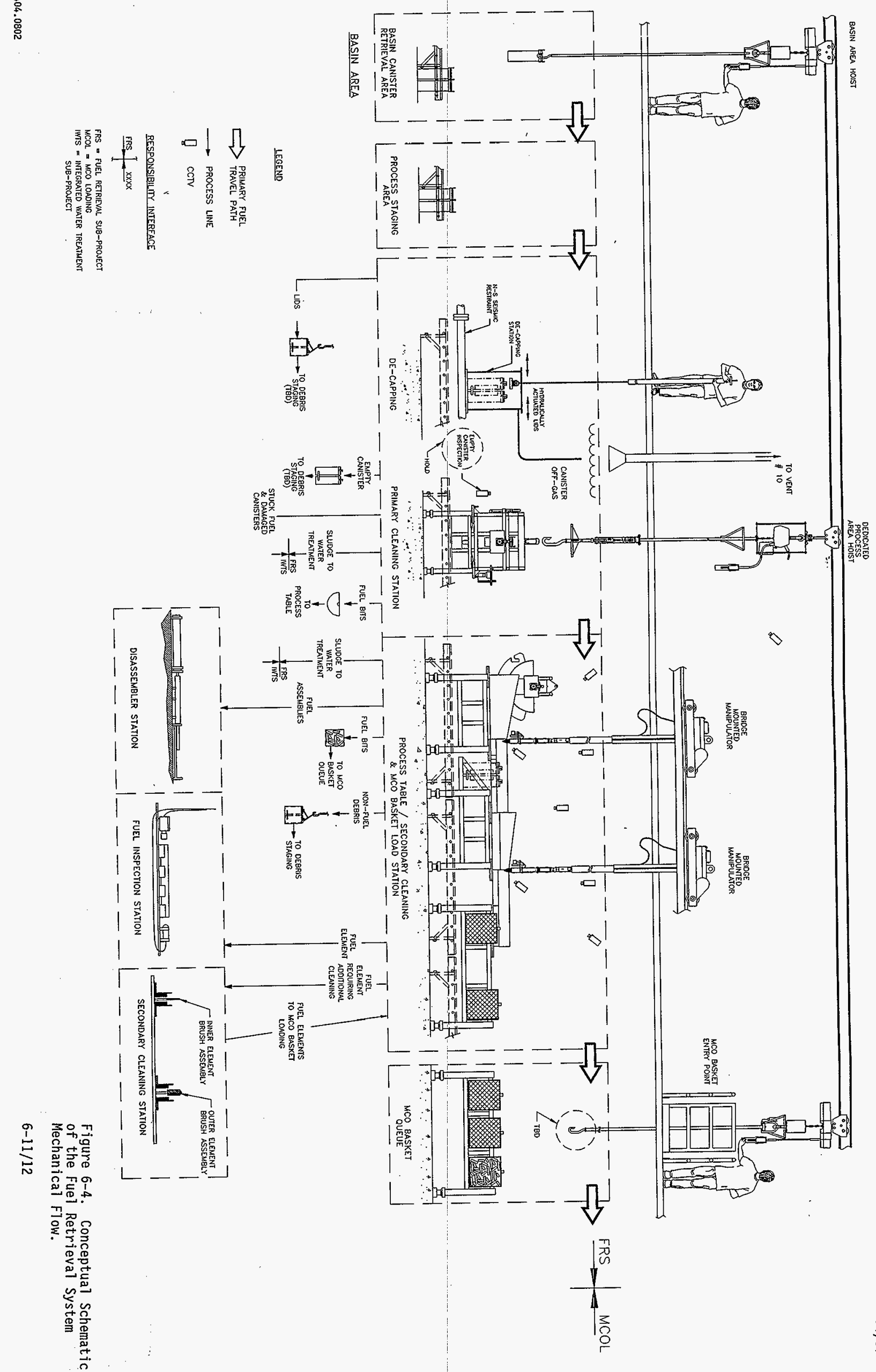
- Manipulators--The underwater manipulators, which are operated hydraulically and controlled remotely (refer to Figure 6-4), will be used to handle fuel elements, fuel scrap, and debris on the process table. The manipulator support will consist of the bridge support structure installed over the in-pool process table within the west bay of the basin.

- Cameras and lighting--Underwater closed-circuit television cameras and related lighting will be provided to support fuel inspection and fuel handling operations. Control and operation of the closed-circuit television will be provided from a remote location (Figure 6-1).

- MCO Basket queue--The MCO basket queue (refer to Figures 6-1 and 6-4) will consist of stands located underwater near the south loadout pit that will hold the loaded MCO baskets. The basket queue will be a simple rigid steel structure designed to hold the weight of the loaded MCO baskets under al1 expected conditions.

- Equipment Operations Center--The equipment operations center (EOC) is located in the existing office area adjacent to the basin. The EOC, a remote (noncontaminated) operations station, provides for the operation of the hydraulic manipulators, closed-circuit televisions, and general surveillance. Communication among operators will be possible with a two-way radio system. Enhanced radiation monitoring will be provided by the installation of a portable gamma radiation monitor in the FRS process area.

- Stuck Fuel Equipment--This underwater equipment will include an apparatus to hold the canister and long-handled tools that will allow stuck fuel to be loosened. This apparatus al so could be provided for mechanically slitting. the canister walls to remove stuck fuel. All stuck fuel operations will be conducted underwater.

- Canister Decapping Equipment-- The canister decapping equipment, unique for the 105-KW Basin, will include existing long-handled tools used to vent and remove the fuel canister caps. Canisters will be opened within an enclosure at the bottom of the basin that is designed to direct the released canister liquid into the IWTS intake. Gases released when the canisters are decapped will be collected at the top of the enclosure and routed to just below the water surface via flooded flexible tubing. Just above the water, a collection hood will be connected to a forced air ventilation system that will provide positive flow and volumetric dilution of the canister gases to preclude the accumulation of hydrogen. The ventilation system will disperse the gases, unfiltered, into the general basin airspace. The design flowrate for this system will be less than 450 cubic feet per minute. The primary purpose of the gas ventilation system is to dilute and disperse the krypton and hydrogen gases refeased during decapping.

6.1.1.2 Fuel Retrieval System Equipment Operation. The FRS operation will retrieve the fuel from storage locations in the basin, clean the fuel, load 
the fuel into MCO baskets, and will queue the baskets for MCO loading. Sludge generated during the cleaning process will be collected into the IWTS and pumped to the siudge accumulation area(s) via the IWTS interface with the primary clean machine and the stuck fuel equipment (if needed). Debris material collected during the fuel cleaning process will be stored in the basin for later removal using the controls discussed in Section 8.0 and descriptions provided in Section 6.3. All FRS operations occur underwater.

The SNF is stored underwater in closed canisters containing up to 14 fuel assemblies per canister. Some single pass reactor (SPR) fuel (Section 7.0) also is stored in.canisters: Fuel canistelns will be retrieved from the basin, decapped, and will be placed, as needed, ill existing fuel storage racks in front of the primary clean machine. After decapping, the primary clean machine will clean the canister and the fust by a combination of mechanical agitation and water sprays. This mechanicil action also will serve to loosen any fuel that could be stuck in the canister. Sludge and fuel corrosion particles loosened during the cleaning will be directed into the IWTS.

The fuel will be tipped out onto the process table (Figure 6-4) where the fuel will be sorted, disassembled, and inspected as necessary. The fuel will be sorted to separate out non-fuel debris and fuel scrap (fuel element pieces shorter than 3 inches in length). Fuel scrap will be loaded into an Mco scrap basket located on the process table. Non-fuel debris will be loaded into a debris bin on the process table. Filled debris bins will be transferred to a debris staging area for later removal from the basin using the controls discussed in Section 8.0 and descriptions provided in Section 6.3

Fuel assemblies (consisting of an inner and outer element), as shown in Figure 6-5, may need to be picked up and reitated to a vertical orientation to separate the inner element from the outer tlement. Fuel elements that do not disassemble by this method may be loaded irito an underwater disassembly station to separate the inner and outer elements by mechanical means.

Fuel elements will be inspected for cleanliness. Clean fuel elements will be transferred directly to the MCO basket loading area of the process table. Fuel elements that fail the cleanliness inspection will be cleaned underwater in the secondary cleaning staticn as necessary. The secondary cleaning station will use mechanical or hyoraulic means to remove residual sludge from the fuel elements.

Following cleaning and inspection, the fuel elements will be loaded into MCO fuel baskets. Fuel that does not meet the fuel element criteria will be loaded into an MCO scrap basket. When MCO fuel baskets and MCO fuel scrap baskets are filled, these will be moved to the MCO loading queue using a transfer.crane and hoists.

It is expected that the fuel can be demonstrated to be clean without subjecting the fuel to all of the cleaning steps. Operating plans include a stage of the primary process validation strategy that will demonstrate the adequacy of the first cleaning process during startup of the system. During the process validation phase, all the disassembled fuel will be inspected to verify that the primary clean machine is adequately cleaning the fuel. 
D0E/RL-97-28, Rev. 0

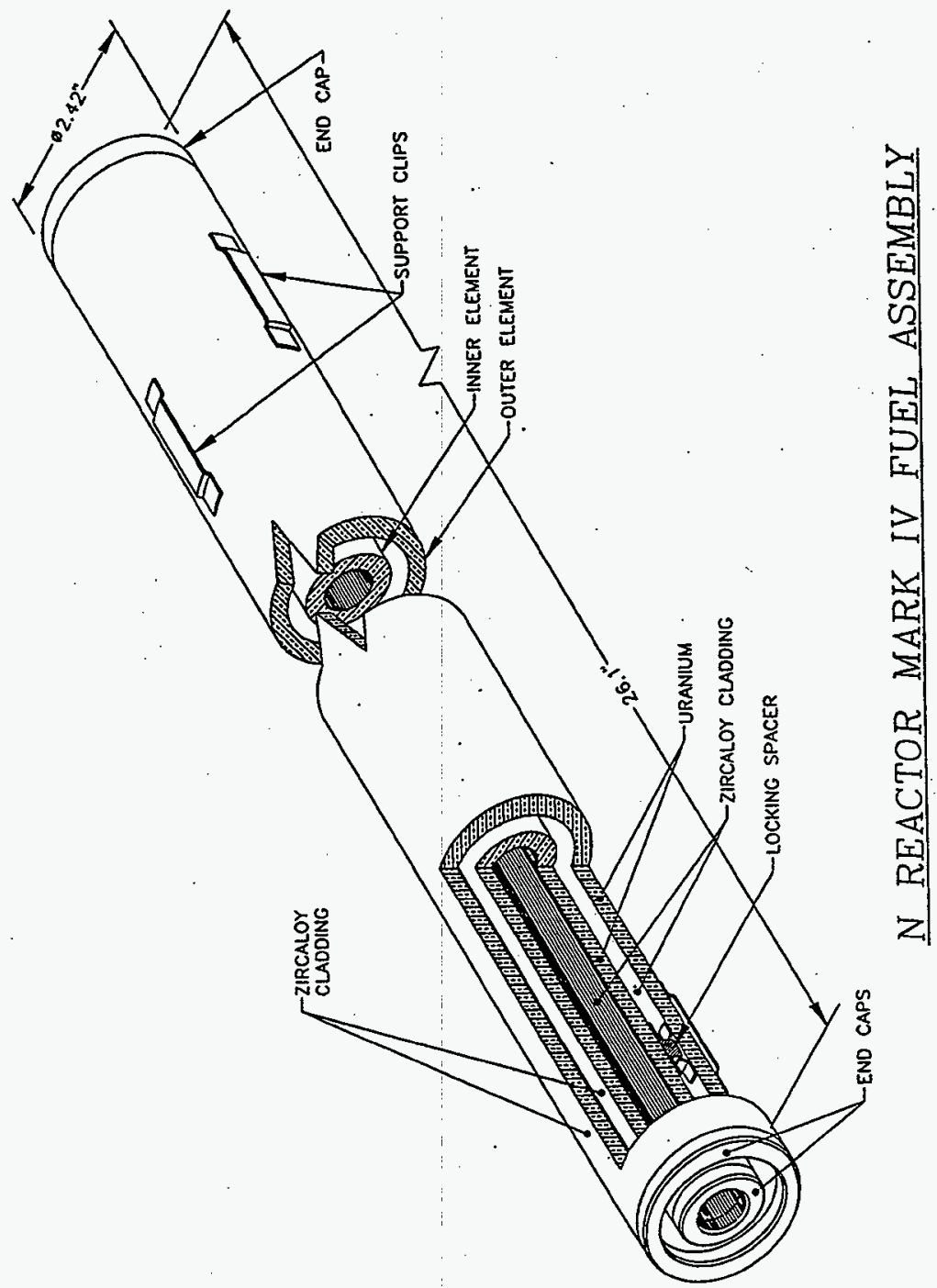

Figure 6-5. Fuel Element with Inner and Outer Elements. 
1 If the validation is successfully completed, clean fuel will be loaded

2 directly into MCO baskets from the canisters, bypassing secondary cleaning.

3 To ensure that the system is continuing to properly clean the fuel, assemblies

4 will be sampled periodically and inspected before loading. in the MCO basket.

5 Inspection of each of the loaded fuel baskets will provide additional

6 assurance that the cleaning process is functional.

6.1.1.3 Fuel Retrieval System Equipment Maintenance. Maintenance of the FRS is expected to include routine removal of the manipulators from the basin for 


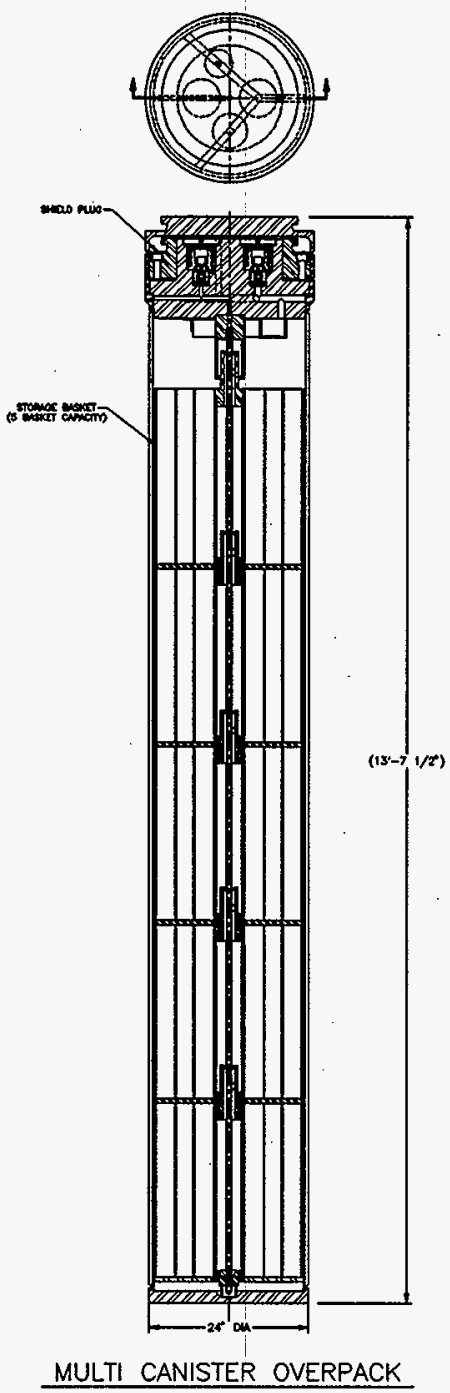

Figure 6-6. Multi-Canister Overpack with Mechanical Closure Assembly. 


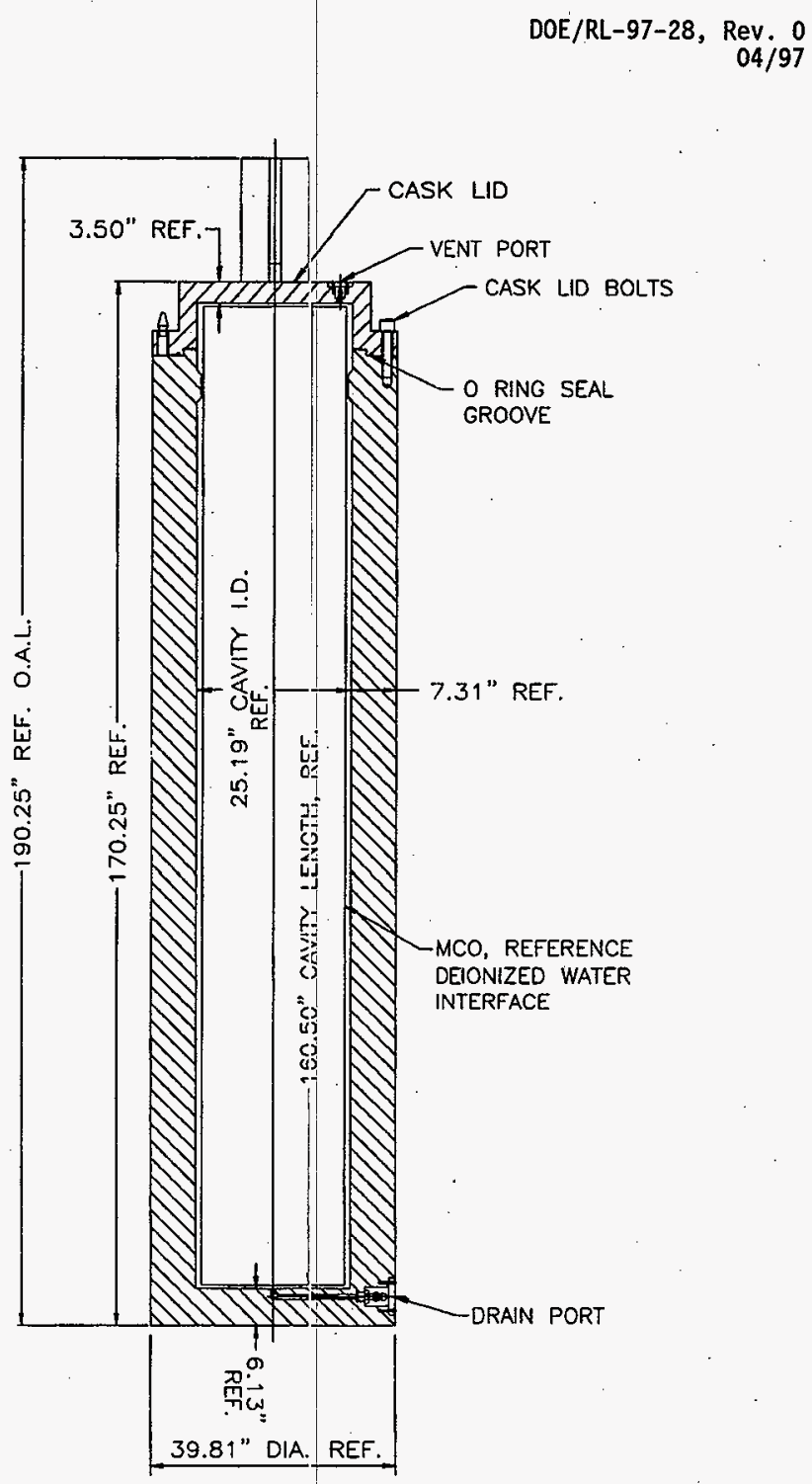

Figure 6-7. Cask Assembly. 
The closure 7 id is removable to allow placement and removal of an MCO. The cask lid is secured to the cask body by bolts.

There are two penetrations through the cask, one located in the cask body at the lid end (designated the vent port) and the other in the cask bottom (designated the drain port). The penetrations are used to drain, dry, backfill, and vent the containment boundary, or circulate warm water in the interspace between the cavity wall and the MCO during operations subsequent to the transfer to the CVDF. All cask penetrations will be closed and sealed during transport.

The cask closure lid is a bolted flanged plate made from stainless steel. Lifting trunnions are provided for engagement with the transfer bay crane. One dovetail seal groove is machined in the underside of the lid flange. An 0-ring is installed in this groove to provide a seat.

6.1.2.3 Immersion Pail. The immersion pail (Figure 6-8) is a box type of structure that will be used in the loadout pit to provide a physical separation between the interior and exterior surfaces of the cask and the radiologicalfy contaminated basin water. The MCO and immersion pail will be filled with clean deionized water.

The immersion pail lid is fabricated of stainless steel. The lid will be held in place through seal pressure, dead weight, and bolts to the main pail structure. The 7 id design limits sea 7 crevices and pool water entrapment, allows flushing of the seal surface before breaking the seal, and allows clean immersion pail water to flow from the seal boundary when seal pressure is removed. Each of these features will support ease of decontamination during the operation sequence.

The immersion pail with a sealing lid will enclose the cask in a cavity filled with clean deionized water. Preumatic seal contact surfaces between the immersion pail seal lid and immersion pail, and between the seal 1 id and MCO, will contain an internal immersion pail positive pressure relative to external hydrostatic pressure during all in-pit operational sequences. Use of the sealed immersion pail precludes contamination by basin water of the exterior and interior surfaces of the cask.

6.1.2.4 Conveyance Vehicle. The conveyance (trailer) vehicle (Figure 6-9) is a semi-trailer that can be attached to a standard tractor. The trailer provides. the necessary supports and attachment points for securing the cask in the vertical orientation during transport to the CVDF.

6.1.2.5 Multi-Canister Overpack Loading System. The MCO loading will be accomplished by backing the conveyance vehicle and tractor into the basin at the west end of the 105- KW Building (refer to Figure 6-1). The tractor will be removed from the basin and the rollup door closed. The cask with (a new) MCO will be lifted by the overhead crane into the immersion pail located in the loadout pit. The cask lid will be removed. 

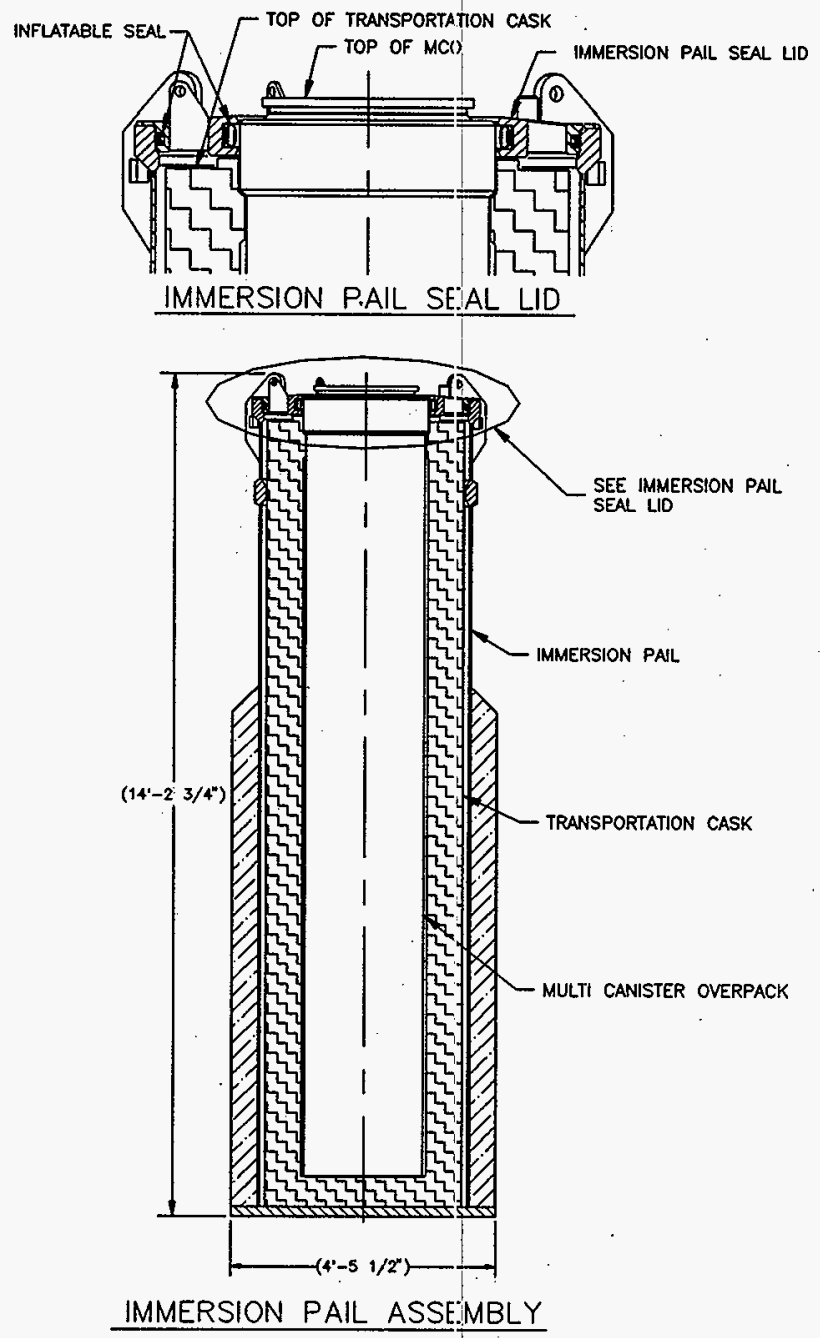

Figure 6-8. Immersion Pail Interfaces. 


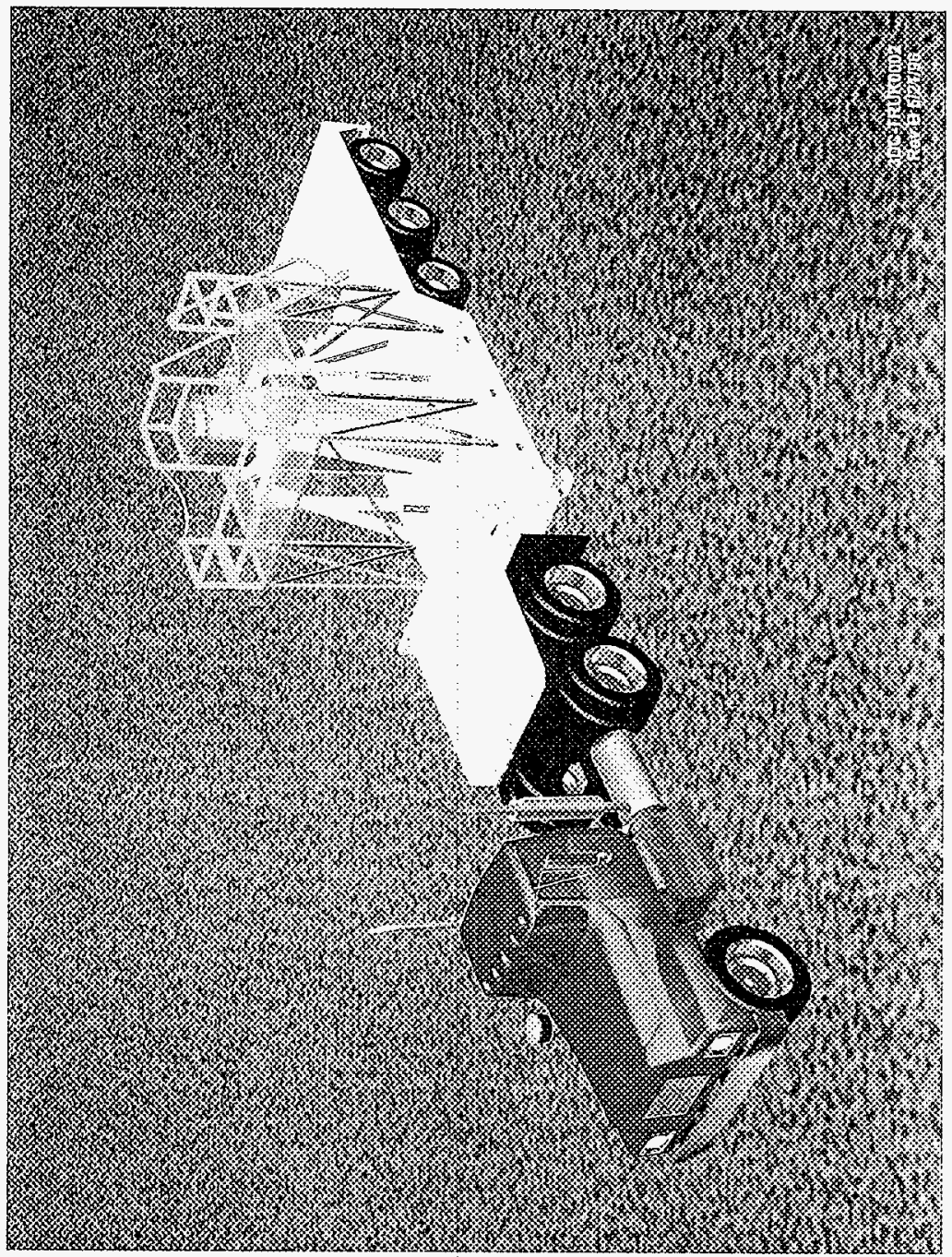

Figure 6-9. Cask and Conveyance System. 
This page intentiona ly left blank. 
DOE/RL-97-28, Rev. 0

04/97

Before submerging the immersion pail into the basin, both the MCO and immersion pail will be filled with clean deionized water. A lid will be attached to the immersion pail and will be sealed by inflation. The immersion pail will be lowered to the bottom of the loadout pit with the MCO/cask ready for loading with MCO fuel baskets. The interior of the MCO will be in contact with the basin water.

After loading of MCO fuel baskets, a shield plug will be installed on the MCO while underwater. The assembly (immersion pail with MCO) will be raised to the top of the loadout pit and rinsed with clean deionized water as it exits the basin water to reduce contamination. The exposed surfaces of the MCO shield plug will be decontaminated, the seals deflated, and the immersion pail lid removed and stored. The cask lid will be installed and sealed via bolting. The cask will be lifted via the overhead crane out of the immersion pail. Surveys of the cask external surfaces will be performed to verify contamination removal before loading onto the trailer. After the cask is secure, the rollup door will be opened, the tractor reconnected to the trailer, and the cask transported to the CVDF.

\subsubsection{Integrated Water Treatment System Overview}

The IWTS will maintain basin water quality during fuel retrieval and removal activities. This system will integrate existing basin water treatment capabilities associated with current fuel storage operations with features that accommodate the increased radionuclide particulates and dissolved solids expected during fuel removal operations.

The IWTS will treat the basin water by filtering, cooling, and providing ion exchange capabilities. Intakes will be configured, as necessary, to provide suction from operations dispersing sludge into the water such as fuet cleaning, sludge pumping, decapping, and debris removal. Some of the resulting treated water will be sent to processes as required. Any excess from the IWTS will be returned to maintain circulation throughout the basin.

The following activities will require water treatment.

- FRS Decapping Station--The decapping station will be connected underwater to the IWTS.

- FRS Primary Clean Machine--The FRS primary clean machine piping will be connected underwater to the IWTS.

- Manual Siudge Movement--The equipment used for this relocation is similar to a swimming pool cleaner, which consists of a hand-held wand and hoses that go directly to the sludge accumulation area. This process wi.11 handle sludge cleanup while the FRS and IWTS are being installed, using the current water treatment system. Once the IWTS becomes operational, the hoses also will have the capability to be routed through the IWTS. The manual system, if required, will remain operational throughout the fuel removal project to supplement the remote system. 


\subsubsection{Integrated Water Treatment System. Water in the basin will be} managed as a closed-loop system, with the water continually being removed from the basin, the majority of which will be circulated through the treatment system and returned to the basin. The IWTS will maintain water quality and temperature in the basin, while providing the necessary collection of cloudy water, treatment of water, and return of treated water to fuel removal processes as necessary. The IWTS will have the following water treatment processes.

- Recirculation System--The IWTS will use the existing basin recirculation piping, but interfaces might be relocated.

- Filtration--IWTS filtration equipment currently is being procured. Performance specifications for this equipment are documented (HNF 1997c). Additional details of this equipment will be provided for review and concurrence that requirements of the permit have been met before installation and operation.

- Ion Exchange - Soluble radionuclides (including but not limited to cesium and strontium that predominate) present in the basin water will be removed using ion exchange resins in a system currently in the procurement process. Additional details of this equipment will be provided for approval before installation and operation. Performance specifications for this equipment are documented (HNF 1997c). Additional details of this equipment will be provided for review and concurrence that requirements of the permit have been met before installation and operation.

- Air Cooled Chiller--An existing chiller, installed in the chiller bay, will be used to maintain the basin water temperature, thus reducing the amount of radionuclides that enter the basin water from the corrosion of the fuel.

- Sludge Accumulation Area--The IWTS may include a provision for the collection of sludge in a confined area(s) underwater in the basin or container(s) above or below the water. The collection of sludge in containers above the water is an option for filtration, with the requirements contained in the performance specification (HNF 1997c). Additional details of this equipmert will be provided for review and concurrence that requirements of the permit have been met before installation and operation of such equipment. The sludge accumulation area(s) will be used to retain sluclge and solids collected in the water treatment system. Excess water will be returned to the IWTS as a closed-loop system. Thus, the sludge accumulation area(s). will be 
used as a settling tank for the solids. It might be necessary to provide a cover over the sludge accumulation area(s) for occupational shielding purposes because of the concentration of the source term and decreasing depth of water cover in this area. If it is necessary to ventilate the airspace under the cover, e.g., to dissipate hydrogen, the exhausted air will be HEPA filtered before reentering the basin airspace as an ALARA best practice. If the HEPA ventilation is installed, a continuous air monitor (CAM) will be operated continuously near the exhaust. Access will be provided to allow personnel to inspect and redistribute the solids as necessary.

- Water Return--Water will be returned to the basin for circulation and project uses. The south side of the basin has the main water return for basin circulation. The remaining water will be supplied for debris removal, fuel processing, and MCO loadout activities as needs dictate.

- Cartridge Filters--Two disposable cartridge filters will be part of the IWTS recirculation system. These were part of the original basin water treatment system and are valved out at this time. If required, this system might augment the other IWTS equipment identified previously.

- Skimmer Loop--The skimmer loop is located on the north side of the basin and uses a backwashable sandfilter for filtration. The sandfilter, which is part of the original water treatment system, discharges water to the west bay of the basin after being filtered. When the sandfilter is backwashed, the effluent currently goes to the north loadout pit and may be backflushed to alternate sludge accumulation area(s). The sandfilter may be operated during fuel removal. If required, this system will augment the other IWTS equipment identified previously.

6.1.3.2 Water Addition. At times, water might need to be added to the basin for makeup and cleaning of equipment. An anion/cation deionization system will be used to add clean water. Other uses for this water will be connections for $\mathrm{MCO} / \mathrm{cask}$ loadout flushing and general future use connection points.

During a major basin leak (earthquake); an emergency fill water system from the service water line is, and will continue to be, in place to fill the basin. This emergency fill water is part of the original water system.

6.1.3.3 Excess Water Removed From the Basin. In the transfer bay area, there will be the capability to remove excess treated basin water through the IWTS piping. Water will be removed via a connection located in the transfer bay. This water will be pumped to a tanker truck and transported to the 200 Area Effluent Treatment Facility (200 Area ETF). The tanker truck will be equivalent to the truck currently being used to transport water from the $100 \mathrm{~N}$ Emergency Dump Basin to the 200 Area ETF. The tanker truck will be located either in a transfer bay or in an adjacent enclosure. 
6.1.3.4 Integrated Water Treatment Systen Operation. The operation of the IWTS has been designed to minimize operator involvement. The IWTS will use manual, remote, and automated techniques for operational control.

- Operation During IWTS Change Over--The current water treatment system will remain operational during the installation of new and relocated equipment for the IWTS. It might become necessary to have the current water treatment system offline when connections are made from the current water treatment system. This is planned to be minimal and the water quality will be monitored during this time.

- Minimum Water Treatment Operation for Underwater Activities--The IWTS will have the capability to controf water quality in the basin. This will be accomplished by bringing those systems online, as needed, to achieve the desired water quality. Minimum system configuration is discussed in Section 8.4. Additional equipment will be placed online as necessary to maintain water quality.

- Operation of IWTS--Certain valve configurations, sampling, and system surveillances will be performed manual1y. Automatic operations will include backwashing filters, sludge relocation operations to the sludge accumulation area, and others designed into the system. A11 remote and automatic operations will be performed from the EOC. Automatic features will be equipped with manual overrides.

\subsubsection{Integrated Water Treatment System Maintenance. The IWTS will be} designed with appropriate access to facilitate maintenance. The following are general maintenance items for the IWTS.

- Pumps, valves, and associated piping connections are designed for ease of decontamination, replacement, and repair of seals. The design minimizes potential crud traps (such as dead legs, socket welds, and 90-degree bends) and provides for flushing before maintenance or removal operations. Discarded units will be bagged and disposed as solid waste."

- IXMs, located in the transfer bay, will be connected and disconnected manually, moved by the overhead crane inside the building onto a truck for disposal as low-7evel waste, similar to present practice.

- The disposable cartridge filters are original water treatment system equipment. If these become clogged with sludge, the filters will be changed.

- The sandfilter currently is backwashed to the north loadout pit, when required.

\subsubsection{Sludge Relocation}

The capability to relocate the 105-KW Basin floor sludge and canister 
equipment used for this removal will be similar to that used in swimming pool cleaning, consisting of a hand-held pole with a vacuum head, an underwater pump, and hoses that are routed to the sludge accumulation area(s) or directly into the IWTS piping.

\subsection{FACILITY MODIFICATIONS}

The following information describes the activities that will occur during the installation of the new equipment (Section 6.1).

\subsubsection{Genera] Construction Activities}

General construction activities identified thus far include the following which might include handling of low-level contaminated materials. Any additional activities necessary will be conducted within the bounds of projected air emissions identified in Section 11.0, Table 11-2. AT1 activities will be performed using standard personnel protective equipment, ALARA practices, and the specific controls discussed in Section 8.0.

- Above Water Work

- Drilling including, but not limited to, steel, wood, asbestos, concrete

- Asbestos removal and replacement

- Grinding, cutting, and abrading of metals

- Carpentry activities

- Helding activities

- Electrical wiring installation, reconfiguration, and rerouting

- Pipe, hose, and valve installation, reconfiguration, and rerouting

- Instrument installation, reconfiguration, and rerouting

- Heating and cooling equipment installation, reconfiguration, and rerouting that does not impact airfiow in or out of the building

- Paint and coating removal and application

- Structural steel removal, replacement, reconfiguration, and upgrade

- Cement, mortar, grouting and concrete removal, replacement, reconfiguration, and installation

- Lifting, hoisting, lowering, dragging, pulling, and pushing of construction supplies and equipment

- Use of gas engines and electric motors

- Use of hydraulic, pneumatic, and electric hand-tools and equipment

- Pump (for transport of water, air, or grouting) installation, use, reconfiguration, and removal

- Manually operated equipment installation, reconfiguration, and removal

- Remotely operated equipment installation, reconfiguration, and removal

- Nondestructive testing

- Use of portable heaters for personnel comfort

- Obsolete and unused equipment disconnection and removal

- Debris removal, under conditions listed in Section 6.3. 
- Below Water Hork

- Drilling including, but not limited to, concrete

- Grinding, cutting, and abrading of metals

- Pipe and hose installation, reconfiguration, and rerouting

- Cement, mortar, grouting, and concrete removal, replacement, reconfiguration, and instaliation

- Fuel movement, under conditions 1isted in Section 6.3

- Obsolete and unused equipment disconnection and removal

- Manually operated equipment installation, reconfiguration, and remova]

- Remotely operated equipment installation, reconfiguration, and removal

- Nondestructive testing

- Debris relocation

- Pump (for transport of water, compressed air, sludge and grouting) installation, use, reconfiguration, and removal.

\subsubsection{Fuel Retrieval System}

The following information describes the activities that will occur during the construction of the FRS equipment previously described in Section 6.1., which might include handling of low-level contaminated materials. Any additional activities necessary will be conducted within the bounds of projected air emissions identified in Section 11.0, Table 11-2. Al1 activities will be performed using standard personnel protective equipment and ALARA practices.

- Above Water Work - Installation/resonfiguration of:

- Basin building structural steel and overhead trolley raj1 upgrades

- Hydraulic system

- Radiation shielding where necessary

- New fuel handling hoists

- Basin grating

- Electrical and mechanical utility services

- EOC.

- BeTow Water Work - Installation/reconfiguration of:

- Process table

- Primary clean machine

- Manipulators

- Lights and cameras

- MCO basket queue

- Seismic restraints

- Remaining process equipment.

\subsubsection{Multi-Canister Overpack/Cask Loadou: System}

The following information describes the activities that will occur during 
Any additional activities necessary will be conducted within the bounds of projected air emissions identified in Section 11.0, Table 11-2. All activities will be performed using standard personnel protective equipment and ALARA practices.

- Above Water Work

- Reroute miscellaneous conduit

- Install windbreak and upgrade rollup door components

- Upgrade compressed air system

- Relocate/install radiation detector

- Install rinse and decontamination water piping

- Install electrical and mechanical utilities

- Decontaminate and seal conveyance vehicle driving surfaces

- Decontaminate and seal cask receiving area

- Prepare laydown and decontamination area(s)

- Upgrade transfer bay crane (replacement in-kind)

- Upgrade building structure - instal1/relocate structural steel (replacement in-kind)

- Install MCO loading system (above water components and structure)

- Install immersion pail and support structure (above water components and structure).

- Below Water Work

- Install MCO loading system (below water components and structure)

- Install immersion pail and support structure (below water components and structure)

- Remove canister elevator and general debris from transfer channel

- Install MCO loading system in south loadout pit (to include sludge/sediment relocation and floor surface preparation including grouting to level floor as necessary).

\subsubsection{Integrated Water Treatment System}

The following information describes the activities that will occur during the construction of the IWTS previously described in Section 6.1. Any additional activities necessary will be conducted within the bounds of projected air emissions identified in Section 11.0, Table 11-2. All activities will be performed using standard personnel protective equipment and ALARA practices.

- Above Water Work

- Replace basin recirculation pump

- Install electrical and mechanical utility services

- Install sludge accumulation area(s) pump and interconnected piping to IWTS as described in Section 6.1.4.

- Install filtration and ion exchange equipment

- Below Water Work

- Install pumps and hoses connecting FRS processes to IWTS

- Install filtration and ion exchange equipment as necessary 


\subsubsection{Water Returns to the 105-KW Basin from Cold Vacuum Drying Facility}

During processing at the CVDF, most of the water and some of the particulates will be removed from MCOs. It might become necessary to return the water removed to 105-KW Basin. If the excess water is returned, the water would be treated first by ion exchange and filtration to reduce the radionuclides.

The liquid at the CVDF will be transferred to 105-KW Basin by tank trucks. A temporary building may be provided outside the transfer bay to house the truck unloading/loading facility. The truck unloading will include provision for a spill containment pan for the tanker, piping, pump, and instrumentation. For unloading, the tanker truck will be connected to the pump using flexible hose and quick disconnect fittings. Any leakage from the fittings will be cleaned up promptly so that the work area is maintained with no smearable radioactive contamination.

The pump discharge would be hard-piped into the basin and routed to the water treatment system. An average of approximately 60,000 gallons of water per year could be transported from the CVDF.

\subsection{DEBRIS REMOVAL DESCRIPTION}

Debris is defined as anything (e.g., scrap, equipment, and material) that is over 0.25 inch in largest dimension that is not a permanent structure within the basin, is not used for current or planned operations or maintenance activity, and is not fuel or sludge. Debris would include such things as empty fuel canisters, old equipment, hand tools, and miscellaneous irradiated and non-irradiated scrap. The quantity of debris in 105-KW Basin is minimal compared to that in the 105-KE Basin, and will consist mostly of the 3,800 existing canisters that will be emptied. Any debris removed will be packaged for disposal in accordance with onsite methods.

Debris removed directly from the water either will be promptly bagged or otherwise contained or be removed into a greenhouse. Available options for rinsing debris include using water obtained from either the existing water treatment system discharge or deionized makeup system. Debris that requires sizing to fit into a disposal container will be cut either under water with cutters or bagged, taped, and cut with cutters above water. Some debris could be placed in containers underwater, and the container removed from the water, rinsed, decontaminated, and properly dispositioned if necessary due to high personnel dose rates.

Canister cleaning and removal would not take place until the fuel is removed from the canisters for repackaging as part of fuel retrieval. It might be necessary to construct and instail canister cleaning equipment underwater.

Specific debris removal equipment and operation will be as follows. The monorail, hoist, and trolley will be used cor transferring debris underwater in the basin. Long-handled tools will be used as required to manipulate items 
under water. The following equipment al so might need to be installed in the basin:

- Above Water Work - Installation/reconfiguration of engineered containment as necessary

- Below Water Work - Installation/reconfiguration of:

- Cutters

- Pressure washing system

- Canister cleaning equipment.

All activities will be conducted within the bounds of projected air emissions identified in Section 11.0, Table 11-2'. All activities will be performed using standard personnel protective equipment and ALARA practices. Engineered containment will be provided as necessary to ensure the emissions do not exceed those forecast in Section 10, Table 10-1.

\subsection{SLUDGE SAMPLING}

It might be necessary to collect and transfer sludge samples from the floor and pit areas before fuel transfer activities. Selected samples will be taken using specially designed portable equipment similar to that previously used for sludge sampling in 105-KE Basin. This equipment will use a peristaltic pump that fills a sample container with a liquid slurry of basin water and floor solids. Because the design incorporates check valves used

27 within the sample lines, the sample never is directly exposed to the air. 
This page intentiona ly left blank.

DOE/RL-97-28, Rev. 0

1
2
3
4 


\subsection{ANNUAL POSSESSION QUANTITY AND PHYSICAL FORM \\ (Requirements $8,10,11$, and 12)}

The following discussion is presented to provide the reader with an understanding of the approximate quantity of radioactive material to be handled during the course of the proposed activities. However, the inventory identified is not used to directly calculate the projected emissions in Sections 10.0 and 11.0 .

The 105-KW Basin contains approximately 961 MTU of N Reactor fuel (approximately 3,800 canisters) and 22 canisters filled with 2.9 MTU of SPR fuel. The $N$ Reactor fuel consists of sightly enriched metallic uranium completely enclosed and bonded to a layer of zirconium alloy (Zircaloy-2), al so known as the cladding. The SPR fuel is very similar, except the fuel is of smaller dimensions and is clad in aluminum. The cladding is designed to provide a barrier against the escape of the radionuclide source term (fission products and fissile materials).

The N Reactor fuel was discharged between 1975 and 1987 . The fuel has decayed sufficiently to essentially eliminate iodine-131, as well as other short half-life radionuclides. Following discharge of the fuel from the $\mathrm{N}$ Reactor, the fuel was allowed to cool for a minimum of 150 days in N Basin. The fuel was encapsulated in closed canisters, loaded onto railcars, and transported to the 105-KW Basin for storage. Some of the canisters are suspected of leaking and contribute to the ongoing need to treat the basin water to remove radionuclides to maintain constant levels in the basin water. Nevertheless, the closed canisters have resulted in there being considerably less (floor) sludge in the 105-KW Basin than in the 105-KE Basin.

The fuel cladding integrity generally is assumed to be better than that in 105-KE Basin, and to have oxidized and deteriorated to a substantially less degree than the fuel in 105-KE Basin. Very limited data (WHC 1995c) on a few canisters that have been opened to date have confirmed this. The study also confirmed that relatively small amounts of sludge were found after screening the canisters. Recently, a more extensive sampling and inspection of 105-KW Basin canisters were completed. These studies were in contrast to the initial studies and showed a much larger degree of deterioration of the fuel inventory in KW basin. The sampling of cesium-137 concentrations in the canisters allowed projections to be made of the entire population (HNF 1997a). Best estimates are that the average canister contains about 2.1 curies of cesium-137 dissolved in the canister water. The presence of this quantity of cesium in the water indicates that corrosion of the fuel has progressed more than had been thought. Further discussion of the fuel corrosion is provided in Section 7.1.3.

\subsection{SOURCE TERH DESCRIPTION}

The following sections provide a discussion on fuel elements, basin water, sludge, surface contamination, and the annual possession quantity. 


\subsubsection{Fuel Elements}

The radionuclide inventory of the irradiated fuel is shown in Table 7-1, decayed to January 1, 1997 (WHC 1995a). The irradiated fuel is the total source term in 105-KW Basin. The source term for all the potentially significant constituents is presented in Table 7-1 (constituents with an activity of less than 1 curie each were not included, but are avajlable in the source document). The quantity presented in Table 7-1 represents the total available inventory of the basin, whether still in the fuel, in the water, or in the sludge.

\subsubsection{Basin Water}

The water in the 105-KW Basin provides both cooling and shielding. The sludge and fuel are immersed in $1.3 \times 10^{6}$ jallons of water. Despite the size of the source term in the fuel and sludge, a relatively small fraction is present in the basin water.

Table 7-2 represents data from a routine analys is for selected basin radionuclides taken October 1, 1996. Predominant isotopes present in the water were tritium (0.28 curie), strontium-90 (0.05 curie), and cesium-137 $(0.66$ curie). Except for tritium, varying levels are achieved depending on the operation of the water treatment systems. These data are presented for information as to the relative quantities present in the water.

The radionuclides of significance in the airborne emissions are known to be particulates that originate from the basin water. The primary mechanisms responsible for airborne contamination are transport at the water line of the basin, and resuspension of surface contamination on basin floors, gratings, and tools (WHC 1993c). The 105-KW Basin was epoxy coated before filling, whereas the 105-KE Basin has uncoated walls. It is suspected that the mechanism for airborne emissions might be less active in 105-KW because of the wall coating.

\subsubsection{Sludge}

Detailed estimates are not available for the 105-KW Basin sludge, but the source term is fully accounted for in Table 7-1. In general, the depth of sludge on the floor has been observed to be minimal (much less than 1 inch), but depths have not been more specifically characterized. The basin sludge is thought to be mostly dust, dirt, paint chios, and other extraneous materials. The north loadout pit has been determined to hold 3.6 cubic meters of sludge (from sandfilter backwashes) and smaller quantities are known to exist in the south loadout pit (from previous cask loading/unloading operations) and view pit (from previous cartridge filter changeouts).

Studies are planned to assess the canister sludge and some studies currently are underway. Recent studies, involving 50 canisters, measured the cesium-137 concentration in the canister liquid (HNF 1997b). These studies afford an opportunity to estimate the sludge contained in canisters. 
4

5

6

7

8

9

10

11

12

13

14

15

16

17

18

.19

20

21

22

23

24

25

26

27

28

29

30

31

32

33

Tab7e 7-1. 105-KW Basin Radionuclide Inventory (Source Term).

\begin{tabular}{|c|c|c|c|}
\hline Radionuclide & Inventory $(\mathrm{C} i)$ & Radionuclide & Inventory (Ci) \\
\hline $\mathrm{H}^{3}$ & $1.91 \mathrm{E}+04$ & $\mathrm{Cs}^{137}$ & $6.71 E+06$ \\
\hline$C^{14}$ & $3.31 \mathrm{E}+02$ & $\mathrm{Ba}^{137} \mathrm{~m}$ & $6.34 E+06$ \\
\hline $\mathrm{Fe}^{55}$ & $9.77 E+02$ & $\mathrm{Ce}^{144}$ & $2.28 \mathrm{E}+02$ \\
\hline $\mathrm{CO}^{60}$ & $2.22 E+03$ & $\mathrm{Pr}^{144}$ & $2.26 E+02$ \\
\hline $\mathrm{Ni}^{59}$ & $1.99 E+01$ & $\mathrm{Pr}^{144} \mathrm{~m}$ & $2.74 E+00$ \\
\hline $\mathrm{Ni}^{63}$ & $2.19 E+03$ & $P^{147}$ & $2.42 E+05$ \\
\hline $\mathrm{Se}^{79}$ & $4.28 E+01$ & $\mathrm{Sm}^{151}$ & $8.69 E+04$ \\
\hline $\mathrm{Kr}^{85}$ & $3.15 \mathrm{E}+05$ & $E u^{152}$ & $4.87 E+02$ \\
\hline $\mathrm{Sr}^{90}$ & $5.22 E+06$ & $\mathrm{Eu}^{154}$ & $5.62 E+04$ \\
\hline$y^{90}$ & $5.22 E+06$ & $\mathrm{Eu}^{155}$ & $1.15 \mathrm{E}+04$ \\
\hline $\mathrm{Zr}^{93}$ & $2.01 E+02$ & $\mathrm{U}^{234}$ & $4.08 E+02$ \\
\hline $\mathrm{Nb}^{93} \mathrm{~m}$ & $1.20 E+02$ & $u^{235}$ & $1.60 \mathrm{E}+01$ \\
\hline $\mathrm{Tc}^{99}$ & $1.43 \mathrm{E}+03$ & $U^{236}$ & $6.11 E+01$ \\
\hline $\mathrm{Ru}^{106}$ & $5.76 \mathrm{E}+02$ & $u^{238}$ & $3.16 \mathrm{E}+02$ \\
\hline $\mathrm{Rh}^{106}$ & $5.76 E+02$ & $\mathrm{~Np}^{237}$ & $2.70 E+01$ \\
\hline $\mathrm{Pd}^{107}$ & $7.68 E+00$ & $\mathrm{Pu}^{238}$ & $5.12 E+04$ \\
\hline $\mathrm{Cd}^{113 \mathrm{~m}}$ & $1.78 E+03$ & $\mathrm{Pu}^{239}$ & $9.93 E+04$ \\
\hline $\mathrm{Sn}^{121} \mathrm{~m}$ & $3.98 \mathrm{E}+01$ & $\mathrm{Pu}^{240}$ & $5.52 E+04$ \\
\hline$S n^{126}$ & $7.50 E+01$ & $\mathrm{Pu}^{241}$ & $3.02 E+06$ \\
\hline $\mathrm{Sb}^{125}$ & $1.85 E+04$ & $\mathrm{Pu}^{242}$ & $2.42 E+01$ \\
\hline $\mathrm{Sb}^{126}$ & $1.05 E+01$ & $\mathrm{Am}^{241}$ & $1.67 \mathrm{E}+05$ \\
\hline $\mathrm{Sb}^{126} \mathrm{~m}$ & $7.50 \mathrm{E}+01$ & $\mathrm{Am}^{242}$ & $8.16 E+01$ \\
\hline $\mathrm{Te}^{125} \mathrm{~m}$ & $4.50 E+03$ & $\mathrm{Am}^{242} \mathrm{~m}$ & $8.20 E+01$ \\
\hline$I^{129}$ & $3.11 E+00$ & $\mathrm{Am}^{243}$ & $4.89 E+01$ \\
\hline $\mathrm{Cs}^{134}$ & $1.03 E+04$ & $\mathrm{Cm}^{242}$ & $6.67 E+01$ \\
\hline $\mathrm{Cs}^{135}$ & $3.79 \mathrm{E}+01$ & $\mathrm{Cm}^{244}$ & $5.81 E+02$ \\
\hline & & Total & $2.80 E+07$ \\
\hline
\end{tabular}

NOTE: Source WHC 1995a. (Only those isotopes with an activity greater. than $1.0 \mathrm{Ci}$ reported. 
Table 7-2. Radionuclides in 105-KW Basin Water

(October 1, 1996)

\begin{tabular}{|c|c|c|}
\hline Isotope & $\begin{array}{l}\text { Concen'tration } \\
\text { (microcuries per milliliter) }\end{array}$ & $\begin{array}{l}\text { Activity } \\
\text { (curies) }\end{array}$ \\
\hline $\mathrm{Am}^{241}$ & $2.08 \mathrm{E}-08$ & $1.0 \mathrm{E}-04$ \\
\hline$C s^{134}$ & $2.00 \quad E-07$ & $9.8 \mathrm{E}-04$ \\
\hline $\mathrm{Cs}^{137}$ & $1.35 E-04$ & $6.6 \mathrm{E}-01$ \\
\hline $\mathrm{CO}^{60}$ & $3.89 \quad E-08$ & $1.9 \mathrm{E}-04$ \\
\hline$E u^{152}$ & $1.92 \quad E-07$ & $9.4 E-04$ \\
\hline$E u^{154}$ & $1.20 \quad E-07$ & $5.9 \mathrm{E}-04$ \\
\hline$E u^{155}$ & $4.42 \quad E-07$ & $2.2 \mathrm{E}-03$ \\
\hline $\mathrm{Pu}^{238}$ & $1.57 E-08$ & 7.7 E-05 \\
\hline $\mathrm{Pu}^{239 / 240}$ & $1.57 E-08$ & $7.7 \mathrm{E}-05$ \\
\hline$S r^{90}$ & $9.45 \quad E-06$ & $4.6 \mathrm{E}-02$ \\
\hline $\mathrm{H}^{3}$ & 5.87 E-05 & $2.9 \mathrm{E}-01$ \\
\hline Total & & $1.00 E+00$ \\
\hline
\end{tabular}

Note: Volume of basin assumed 4.9 E+09 milliliter.

Projections of these studies for the entire canister population are that an estimated total cesium-137 content in the liquid in al1 3,800 canisters could be as high as 9,350 curies. Assuming this was all released from dissolved fuel, the quantity of sludge (dissolved fuel) can be determined from the fraction of cesium-137 released versus that present in the original intact fuel (Table 7-1 value):

$$
\text { \% Fuel Dissolved }=100 \% \times 9,350 \mathrm{Ci} / 6.79 \mathrm{E}+06 \mathrm{Ci}=0.14 \text { percent. }
$$

This value is about one-half of the estimate for the 105-KE Basin ( 0.33 percent $)$, and seems reasonable given the more protected environment of the canisters. Given uncertainties in sampling and accounting for non-canister sludge, it is expected that the source term of sludge in $105-\mathrm{KW}$ Basin would not 1 ikely exceed twice the above estimate, or 0.3 percent of the source term of the fuel listed in Table 7-1.

\subsubsection{Surface Contamination}

A portion of the interior of the 105-IKW Basin has measurable surface (removable) contamination, Targely in the ransfer bay. Weekly surveys are performed to measure the levels and assess changes in these levels. An administrative control level of $10,000 \mathrm{~d} / \mathrm{m}_{i} / 100 \mathrm{~cm}^{2}$ of $\beta-\gamma$ and $500 \mathrm{~d} / \mathrm{m} / 100 \mathrm{~cm}^{2}$ $\alpha$ is employed, above which the contamination levels are required to be reduced by decontamination to the extent practical. Radiological control requirements dictate that any areas above $100,000 \mathrm{~d} / \mathrm{m} / 1100 \mathrm{~cm}^{2}$ of $\beta-\gamma$ and $2,000 \mathrm{~d} / \mathrm{m} / 100 \mathrm{~cm}^{2}$ $\alpha$ be posted "DANGER, HIGH CONTAMINATION ARI:A". There are no areas so posted. 
Therefore, most above water activities described in this NOC are expected to 2 be conducted either in clean areas or in areas with contamination levels less 3 than the administrative control levels, or $10,000 \mathrm{~d} / \mathrm{m} / 100 \mathrm{~cm}^{2}$ of $\beta-\gamma$ and $4500 \mathrm{~d} / \mathrm{m} / 100 \mathrm{~cm}^{2} \alpha$.

\subsubsection{Gases}

For purposes of estimating releases, the bounding quantity of krypton-85 inside the stored canisters has been determined. This isotope is bound in the fuel matrix and released when the fuel dissolves. The estimates made in Section 7.1.3 can be applied to the gases as we11. The bounding gaseous release of krypton-85 would be 0.3 percent of the Table 7-1 value, or $0.003 \times 3.15 \mathrm{E}+05=945$ curies. Further, because there are approximately 3,800 canisters, the quantity in each canister would be bounded by $945 / 3,800$, or 0.25 curie per canister ( 2 barrels/canister $\times 125,000$ microcuries/barrel). In reality, much of this gas is released through the canister gas trap and is not retained within the canister. Previous sampling of the 105-KW Basin canisters found the krypton-85 content to range from 4,600 to 13,200 microcuries per barrel (WHC 1996a). Assuming the highest value found and applying this value to all barrels, the estimated krypton gas retained in the fuel canisters would be:

\section{$13,200 \mu \mathrm{Ci} /$ barrel $\times 1 \mathrm{E}-6 \mathrm{Ci} / \mu \mathrm{Ci} \times 7,600$ barrels $=100 \mathrm{Ci}$}

The value of 100 curies will be used in release calculations to assess the release on opening the canisters. 
28

29

30

\subsubsection{Source Term for Above Water Work}

An estimate for the source term for above water work will be derived based on 1996 emissions. The above water activities in this NOC are similar to those conducted in 1996 in the 105-KW Basin.

The 1996 activities that occurred and are similar to fuel removal activities are as follows:

- Demolition preceding entry vestibule construction

- Demolition of transfer bay structures

- Sludge sampling and cask shipment

- Piping modifications.

Table 7-3 represents the radioactive air emissions resulting from all 1996 activities in the 105-KW Basin, both above and below water. Because the above water fuel retrieval activities are expected to be similar to those already accounted for in the 1996 emissions, the emissions listed in Table 7-3 are a conservative representation of above water potential to emit (PTE). The source term for above water work was derived by back calculating the source based on a partition (release) fraction of 1 E-03 consistent with 40 CFR 61, Appendix D methodology for particulates.

Table 7-3. Estimated Above Water Source Term In $105 \mathrm{~K}$ West Basin.

\begin{tabular}{|l|c|c|c|c|c|}
\hline Radionucl ide & $\begin{array}{c}\text { Release } \\
\text { in } \\
\text { Curies } \\
(1996)\end{array}$ & $\begin{array}{c}\text { CAP-88 Dose } \\
\text { Conversion } \\
\text { factor } \\
\text { mrem/Ci }\end{array}$ & $\begin{array}{c}\text { TEDE to } \\
\text { the MEI, } \\
\text { mrem/yr }\end{array}$ & $\begin{array}{l}\text { Partition } \\
\text { Fraction }\end{array}$ & $\begin{array}{c}\text { Above } \\
\text { Water } \\
\text { Source } \\
\text { Term }\end{array}$ \\
\hline $\mathrm{CO}^{60}$ & $3.0 \mathrm{E}-07$ & $4.28 \mathrm{E}-02$ & $1.28 \mathrm{E}-08$ & $1.00 \mathrm{E}-03$ & $3.00 \mathrm{E}-04$ \\
\hline $\mathrm{SR}^{90}$ & $2.2 \mathrm{E}-05$ & $6.45 \mathrm{E}-02$ & $1.42 \mathrm{E}-07$ & $1.00 \mathrm{E}-03$ & $2.20 \mathrm{E}-03$ \\
\hline $\mathrm{RU}^{106}$ & $5.4 \mathrm{E}-07$ & $3.08 \mathrm{E}-02$ & $1.66 \mathrm{E}-08$ & $1.00 \mathrm{E}-03$ & $5.40 \mathrm{E}-04$ \\
\hline $\mathrm{SB}^{125}$ & $4.4 \mathrm{E}-08$ & $6.13 \mathrm{E}-03$ & $2.70 \mathrm{E}-10$ & $1.00 \mathrm{E}-03$ & $4.40 \mathrm{E}-05$ \\
\hline $\mathrm{CS}^{134}$ & $7.2 \mathrm{E}-08$ & $4.62 \mathrm{E}-06$ & $3.33 \mathrm{E}-13$ & $1.00 \mathrm{E}-03$ & $7.20 \mathrm{E}-05$ \\
\hline $\mathrm{CS}^{137}$ & $9.1 \mathrm{E}-06$ & $3.53 \mathrm{E}-02$ & $3.21 \mathrm{E}-07$ & $1.00 \mathrm{E}-03$ & $9.10 \mathrm{E}-03$ \\
\hline $\mathrm{EU}^{154}$ & $5.1 \mathrm{E}-08$ & $2.69 \mathrm{E}-02$ & $1.37 \mathrm{E}-09$ & $1.00 \mathrm{E}-03$ & $5.10 \mathrm{E}-05$ \\
\hline $\mathrm{PU}^{238}$ & $2.5 \mathrm{E}-08$ & $1.18 \mathrm{E}+01$ & $2.95 \mathrm{E}-07$ & $1.00 \mathrm{E}-03$ & $2.50 \mathrm{E}-05$ \\
\hline $\mathrm{PU}^{239 / 240}$ & $1.7 \mathrm{E}-07$ & $1.28 \mathrm{E}+01$ & $2.18 \mathrm{E}-06$ & $1.00 \mathrm{E}-03$ & $1.70 \mathrm{E}-04$ \\
\hline $\mathrm{PU} U^{241}$ & $2.5 \mathrm{E}-06$ & $2.03 \mathrm{E}-01$ & $5.08 \mathrm{E}-07$ & $1.00 \mathrm{E}-03$ & $2.50 \mathrm{E}-03$ \\
\hline $\mathrm{AM}^{241}$ & $1.3 \mathrm{E}-07$ & $1.94 \mathrm{E}+01$ & $2.52 \mathrm{E}-06$ & $1.00 \mathrm{E}-03$ & $1.30 \mathrm{E}-04$ \\
\hline & & & & & \\
\hline$T_{0 T A L}$ & $1.5 \mathrm{E}-05$ & & $5.99 \mathrm{E}-06$ & & $1.51 \mathrm{E}-02$ \\
\hline
\end{tabular}


The annual possession quantity is identified in Table 7-1. Table 7-4 represents data on some of the more significant isotopes and their release forms. Tritium and krypton are released routinely during operations due to ongoing fuel corrosion, while the balance of the isotopes are released as particulate solids. As the fuel corrodes, complex compounds are produced for which a simple, concise description is not available.

Table 7-4. Physical Form, Release Form, and Chemical Form.

\begin{tabular}{|l|l|l|l|}
\hline Radionuclide & Physical form & \multicolumn{1}{|c|}{ Release form } & Chemical form \\
\hline $\mathrm{H}^{3}$ & solid & vapor & water \\
$\mathrm{Co}^{60}$ & solid & particulate solid & Various \\
$\mathrm{Kr}^{85}$ & solid & gas & elemental \\
$\mathrm{Sr}^{90}$ & solid & particulate solid & Various \\
$\mathrm{Cs}^{137}$ & solid & particulate solid & Various \\
$\mathrm{Pu}^{238}$ & solid & particulate solid & Various \\
$\mathrm{Pu}^{239 / 240}$ & solid & particulate solid & Various \\
$\mathrm{Pu}^{241}$ & solid & particulate solid & Various \\
$\mathrm{Am}^{241}$ & solid & particulate solid & Various \\
\hline
\end{tabular}

a Radionuclides identified as 'various' form numerous complex compounds. 
This page intentionaliy left blank. 


\subsection{CONTROL SYSTEM (Requirement 6)}

The 105-KW Basin does not provide for inlet supply air and exhausted air is not filtered. Air is exhausted from the building via roof vents, two over the basin and two over the high bay area.

All radioactive particulates having the potential for airborne emissions from the basin will or have originated from the basin water. The primary mechanisms responsible for airborne contamination are transport at the water line of particulates from the basin and suspension of surface contamination on floors, gratings, and tools (WHC 1993b).

\subsection{CONTROL EQUIPMENT}

The existing abatement technology consists of water treatment equipment, ion exchange modules (IXMs), chiller, cartridge filters and sandfilter. This equipment will be used to support the storage operations, and installation of fuel removal equipment. Additional treatment equipment components meeting the requirements of the performance specification (HNF 1997c) will be operated to support the fuel removal activities to control the source term in the water after the canisters are opened.

\subsubsection{Basin Water}

The basin water consists of the $1.3 \times 10^{6}$ gallons of water that cover the irradiated fuel. The basin water is an inherent part of the fuel storage process. The water precludes the radionuclide source term from becoming directly airborne as might occur if the water were absent. The water also provides radiation shielding. All fuel handling operations described in this NOC will be conducted underwater.

\subsubsection{Existing Water Treatment}

The existing water treatment takes place typically with a single IXM, sandfilter, and an air cooled chiller. This treatment is a normal part of fuel storage operations. Cartridge filters are available for water treatment, but normally are not applied because of high radiation exposure to personnel during changeout, the cost for disposal, and adequate treatment can occur without using the filters. Ion exchange columns, historically used for water treatment, are no longer used because of the additional radiological dose that would be incurred by workers handling the unshielded columns.

\subsubsection{Integrated Water Treatment System}

The IWTS (Section 6.1.3) will provide for the removal of particulates and will increase the capacity for removal of radionuclides from the basin water. The IWTS will provide capability beyond that of the existing water treatment 
system and will be engineered to meet the performance requirements and the increased source term that will be exposed to the water during fuel handling activities.

\subsection{CONTROLS FOR ABOVE WATER ACTIVITIES}

Specific controls (as described in WDOH approval letter (AIR 97-206) for 105-KE Fuel Removal NOC conditions 1 and 2) will be applied for individual above water activities. However, the construction activities described will involve, to the most degree, uncontaminated new equipment. Contaminated areas will be decontaminated before work, as practical, or engineered controls, such as glovebags, fixatives, ventilation, or containment, will be applied when required. Any surface contaminated materilis removed will be bagged promptly in plastic and packaged for disposal during routine transports.

Maintenance activities performed on fuel removal equipment will follow practices as stated in Condition 1 of approval letter (AIR 97-206) for 105-KE Fuel Removal NOC. These activities will be conducted in accordance with routine activity contamination control practices, e.g., glovebags, decontamination, fixatives, etc., thus minimizing the PTE. Any items that need to be removed from the water will be rinsed on removal from the water; if these items need to be left out of the water, the items will be first bagged in plastic for storage or subsequent handling within containment.

\subsection{CONTROL EQUIPMENT EFFICIENCIES}

The existing water treatment system contains ion exchange components for removal of radionuclides and particulate $f$ ilters for removal of particulate radionuclides. Removal efficiencies are presented in Tables 8-1 and 8-2. The removal efficiencies for IXMs decrease with increasing run time. The IXMs are changed out when sampling indicates the renoval efficiency for cesium-137 decreases from 99 percent to approximately 70 percent. Time between changeouts varies and depends on basin water quality; changeouts are expected to occur as frequently as every few weeks.

Performance specifications (HNF 1997c) for the IWTS components are currentiy in the procurement process.

Table 8-1. Average Radionuclide Field Measured Maximum Removal Efficiencies of the 105-KW Basin Water Treatment System Components.

Ion exchange module (\%)

\begin{tabular}{|l|c|}
\hline \multicolumn{1}{|c|}{ Radionuclide } & Ion exchange module (\%) \\
\hline Strontium & 99 \\
\hline Cesium & 99 \\
\hline Plutonium & 81 \\
\hline
\end{tabular}


4

5

6

7

8

10

11

12

13

14

15

16

17

18

Table 8-2. Projected Particulate Removal Efficiencies of the 105-KW Basin Water Treatment System Components.

\begin{tabular}{|l|l|l|}
\hline \multicolumn{1}{|c|}{ Component } & Nominal flowrate & \multicolumn{1}{|c|}{ Remarks } \\
\hline Sandfilter & $\begin{array}{l}400 \text { gallons per } \\
\text { minute }\end{array}$ & $\begin{array}{l}\text { Particulate removal at } \\
10 \text { microns or larger. }\end{array}$ \\
\hline Cartridge filter & $\begin{array}{l}450 \text { gallons per } \\
\text { minute each }\end{array}$ & $\begin{array}{l}\text { Disposable cartridge filters } \\
\text { for particles 5 microns or } \\
\text { larger in size (varying } \\
\text { filter sizes are available) }\end{array}$ \\
\hline
\end{tabular}

\subsection{INTEGRATED WATER TREATMENT SYSTEM OPERATIONAL CONTROLS}

The minimum configuration of the existing water treatment system will be at least one IXM operating during underwater operations that disturb the fuel or sludge.

The minimum configuration of the IWTS will be at least one ion exchange and filtration component in operation before handling fuel. No operations that disturb the source term in the water will be conducted if the cesium-137 concentration in the basin water exceeds 30 micro curies per liter. Additionally, at a level of 15 microcuries per liter of cesium-137, incremental water treatment equipment will be placed on-line.

The other elements of the IWTS will be operated selectively depending on water quality process needs. Should the IWTS fail entirely during underwater fuel handling, the operations involving fuel already on the process table may be completed to allow for a safe and orderly shutdown. 
DOE/RL-97-28, Rev. 0

$04 / 97$

This page intentiona ly left blank. 
DOE/RL-97-28, Rev. 0

$04 / 97$

\subsection{MONITORING SYSTEM (Requirenent 9)}

The 105-KW Basin does not provide inlet supply air and exhausted air is not filtered. Air is exhausted from the building via roof vents, two over the basin and two over the transfer high bay area. The combined air flow from the four roof vents is 651 cubic feet per second (WHC 1993b).

The sampling system inside the 105-KW Basin consists of three fixed head samplers. The design of the fixed head samplers allows the filter head to be lowered or elevated for safe changeout and sample collection. The particulate filters from the three samplers are collected weekly. The particulate filters currently are delivered to Quanterra Environmental Services of Richland, Washington. Quanterra Environmental Services performs total alpha/beta analyses on the particulate filters. The contractual detection limits for Quanterra Environmental Services are 1 picocurie per sample. For a typical sample, this is approximately 4.4 E-16 microcuries per milliliter. Weekly filters are composited for a monthly gamma scan, strontium-90, americium-241, and plutonium isotopic analysis. The particulate radionuclides contributing 10 percent or more of the total effective dose equivalent (TEDE) from 105-KW Basin are plutonium-239/240 and americium-241. Of the air emissions measured for calendar year 1996 at 105-KW Basin, 7.7 percent of the alpha emitting actinides were plutonium-238, 52.3 percent were plutonium-239/240, and 40.0 percent were americium-241. For calendar year 1996 at 105-KW Basin, the dose contribution amounts were 2.3 percent due to strontium-90, 4.9 percent due to plutonium-238, 5.3 percent due to cesium-137, 36.3 percent due to plutonium-239/240, and 42.0 percent due to americium-241.

The three samplers are located as follows: two are located over the 105-KW Basin and one is located in the transfer high bay area. The samplers over the 105-KW Basin are positioned directly in front of roof vent 11 and roof vent 10 , the inlet to the exhaust fans. The sample head filter assembly is attached to an adjustable support extended to the inlet of the fan, about 11 feet above the floor. The third sampler is in the transfer high bay area near exhaust fans roof vent 6 and roof vent 7 . The filter assembly for the high bay sampler is approximately 20 feet above the floor. Figure 9-1 identifies the relative position of these fixed head samplers.

The sampler system design eliminates any sample line loss concerns. he particulate filter employed is a 1.85 -inch-glass fiber filter with a 91 percent capture efficiency for particles with a median diameter of 0.3 micron. The sample filter assembly is connected to a vacuum pump via plastic tubing. Because the particulate filter is upstream of the plastic tubing, the particulate filter is not influenced by the tubing. The sample pumps are equipped with a flow regulator. The nominal sample flowrate is 2 cubic feet per minute.

Operational checks of the exhaust fans and the sample pumps are performed each working day. In the event a fan is found not operating or is de-energized for any reason, the sampler is turned off until the exhaust fan is returned to service. The operability information for the samplers and exhaust fans is logged and reported to monitoring program personnel. 


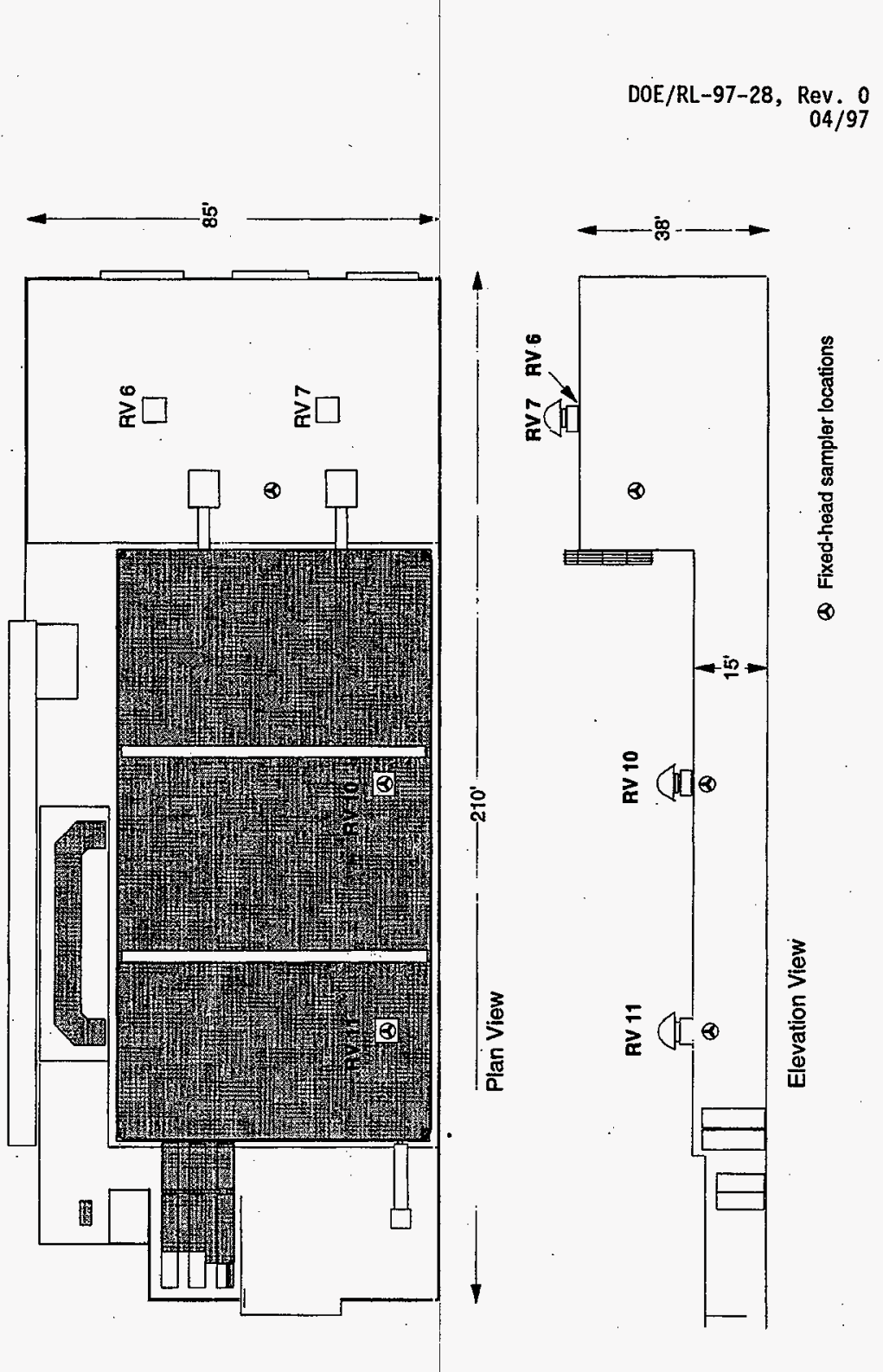

Figure 9-1. Fixed Head Sampler Positions. 
1 The sample pump flowrate is checked bi-weekly using a calibrated National 2 Institute of Standards and Technology traceable flow meter.

3

4

In addition to the system described previously, near-field ambient air monitoring currently is being performed at several locations around the 105-KW Basin. Three monitors, designated as $\mathrm{N}-401,402$, and 403 will continue to be operated until changes are approved by the WDOH. A fourth sampler, designated as $\mathrm{N}-401$ also is in current operation. However, WDOH has approved plans to discontinue use of this sampler and sampling at this site might be 10 discontinued. Figure 9-2 shows the current locations of the four monitoring 11 points. 


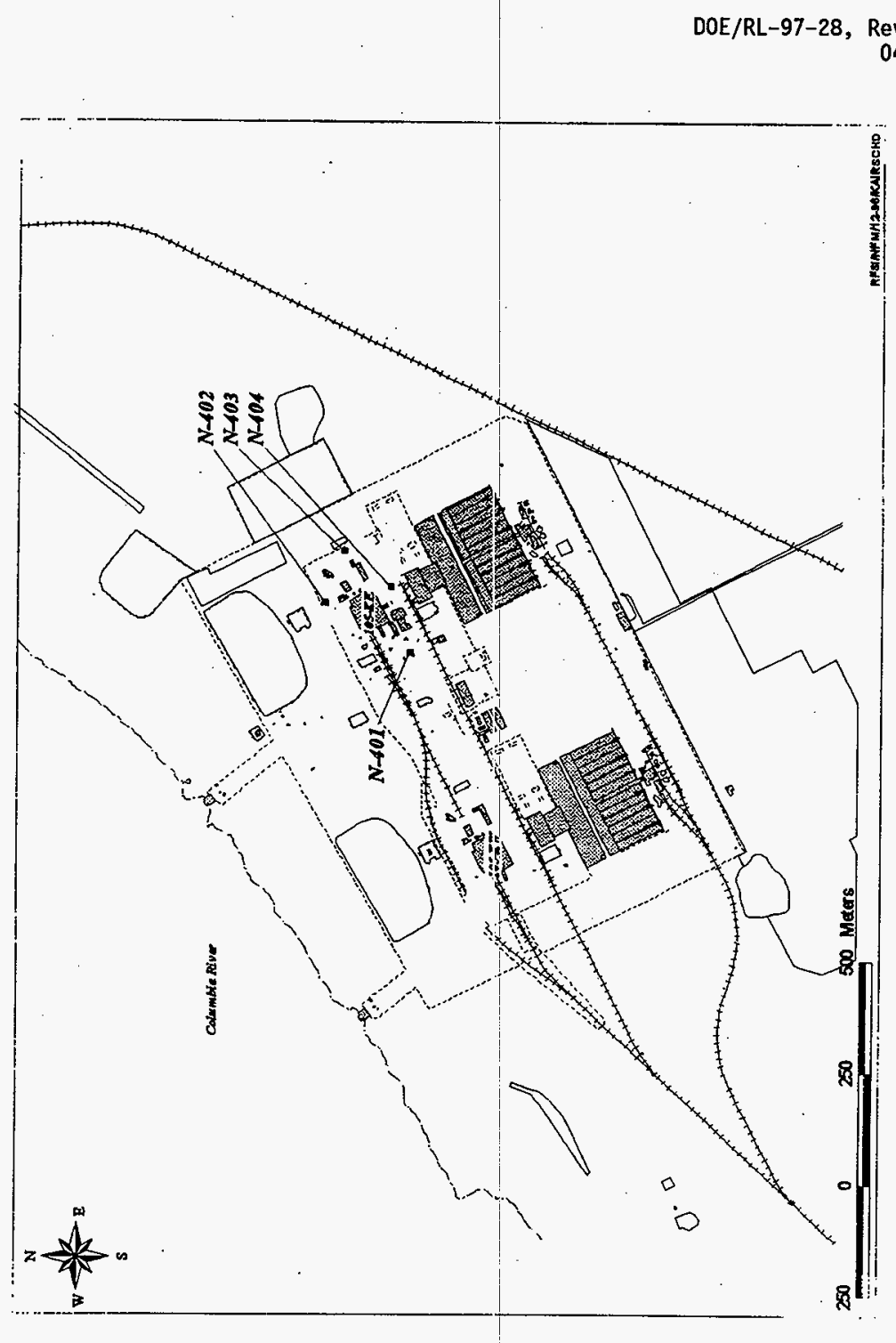

Figure 9-2. Locations of Near-Fie]d Monitoring Locations. 
The following provides projections of potential emissions based on good engineering judgment, actual emissions data, and the required assumptions regarding absence of emissions control equipment.

\subsection{PROJECTED EMISSIONS WITHOUT ABATEMENT CONTROLS IN PLACE (POTENTIAL TO EMIT)}

The PTE for the above water and in-basin activities will be determined by direct comparisons with the 105-KE Basin. The possession quantity (Table 7-1) and 105-KW Basin fuel removal activities are similar to those presented in the 105-KE Basin NOC for Fuel Removal (DOE/RL-96-101). Because the 105-KW Bas in has less siudge or particulate (Section 7.1.3) and overall lower levels of existing contamination, the PTE for the 105-KW Basin will be bounded by the 105-KE Basin. Therefore, the PTE for the 105-KE Bas in fuel removal activities (DOE/RL-96-101) will be adopted directly herein. Table 10-1 lists the projected emissions by isotope. The presence of krypton-85 in the canister gas is accounted for and the quantity (Section 7.1.7) also has been incorporated into Table 10-1.

Table 10-1. Projected Unabated Radioactive Air Emissions (Potential to Emit).

27

28

29

30

31

32

33

34

35

36

37

38

39

40

41

42

43

\begin{tabular}{|c|c|}
\hline Radionuclide & Release (curies) \\
\hline $\mathrm{CO}^{60}$ & $1.4 \mathrm{E}-05$ \\
\hline $\mathrm{Kr}^{85}$ & $1.0 \mathrm{E}+02$ \\
\hline $\mathrm{Sr}^{90}$ & $4.4 E-05$ \\
\hline $\mathrm{Ru}^{106}$ & 8.1 E-05 \\
\hline $\mathrm{Sb}^{125}$ & $1.9 E-05$ \\
\hline $\mathrm{Cs}^{134}$ & 3.4 E-06 \\
\hline$C^{137}$ & $1.8 E-03$ \\
\hline $\mathrm{Eu}^{154}$ & $4.3 \mathrm{E}-05$ \\
\hline $\mathrm{Eu}^{155}$ & $8.9 \mathrm{E}-06$ \\
\hline $\mathrm{Pu}^{238}$ & $1.7 \mathrm{E}-05$ \\
\hline $\mathrm{Pu}^{239 / 240}$ & $1.1 \mathrm{E}-04$ \\
\hline $\mathrm{Pu}^{241}$ & $1.6 \mathrm{E}-03$ \\
\hline $\mathrm{Am}^{241}$ & $4.1 \mathrm{E}-05$ \\
\hline Total & $1.0 \mathrm{E}+02$ \\
\hline
\end{tabular}




\subsection{ANNUAL EMISSIONS}

The following are the results of calendar year 1996 monitoring 105-KW Basin, using the sampling system described in Chapter 9.0. As indicated in Table 10-2, the actual release for all radionuclides is 1.5 E-05 curies.

Table 10-2. Radioactive Air Emissions Measured at $105-\mathrm{KW}$ Basin in Calendar Yeiar 1996

\begin{tabular}{|l|l|c|}
\hline \multicolumn{1}{|c|}{ Radionuclide } & Release (curies) \\
\hline $\mathrm{Co}^{60}$ & $3.00 \mathrm{E}-07$ \\
$\mathrm{Sr}^{90}$ & $2.20 \mathrm{E}-06$ \\
$\mathrm{Ru}^{106}$ & $5.40 \mathrm{E}-07$ \\
$\mathrm{Sb}^{125}$ & $4.40 \mathrm{E}-08$ \\
$\mathrm{CS}^{134}$ & $7.20 \mathrm{E}-08$ \\
$\mathrm{Cs}^{137}$ & $9.10 \mathrm{E}-06$ \\
$\mathrm{Eu}^{154}$ & $5.10 \mathrm{E}-08$ \\
$\mathrm{Pu}^{238}$ & $2.50 \mathrm{E}-08$ \\
$\mathrm{Pu}^{239 / 240}$ & $1.70 \mathrm{E}-07$ \\
$\mathrm{Pu}^{241}$ & $2.50 \mathrm{E}-06$ \\
$\mathrm{Am}^{247}$ & $1.30 \mathrm{E}-07$ \\
\hline \multicolumn{2}{|c|}{ TOta7 } & $1.51 \mathrm{E}-05$ \\
\hline
\end{tabular}

Given the presumably better condition of the fuel in the 105-KW Basin (refer to Sections 7.0 and 7.1.3) than in the 105-KE Basin and the overa17 lower contamination levels, it would be explected that the emissions from the 105-KW Basin would be somewhat lower than in the 105-KE Basin during fuel retrieval. Projected emissions from 105-KW Basin were determined based on good engineering judgment by comparing the 105-KW Basin at fuel retrieval to the present (stored in open canister) fuel configuration in 105-KE Basin. During fuel retrieval, all canisters in the: 105-KW Basin will be opened. The enhanced control technology employed will be similar to that presently used at the 105-KE Basin for water treatment of open canisters, i.e., IXMs or equivalent. Therefore, the projected emissions are expected to be similar to those experienced in recent years in the 105-KE Basin during routine operations with the fuel unencapsulated. Table 10-3 represents a projection of the estimated emissions for fuel retrieval based on good engineering judgment. The values shown represent the highest annual emissions, for each particulate radionuclide, that actually were measured in the 105-KE Bas in for calendar years 1993, 1994, and 1995. (Emission monitoring before that time was considered unreliable by the $\mathrm{WDOH}$ ). Included in this time period were activities in 105-KE Basin that suspended the sludge in the water and 
represented conditions similar to those expected in the 105- $\mathrm{KW}$ Basin during fuel removal.

Table 10-3. Good Engineering Judgment Projected Abated Emissions.

\begin{tabular}{|l|c|c|}
\hline \multicolumn{1}{|c|}{ Radionuclide } & $\begin{array}{c}\text { Average concentration } \\
(\mu \mathrm{Ci} / \mathrm{m} \mathrm{T})\end{array}$ & $\begin{array}{c}\text { Projected annua } \\
\text { emissions (Ci/yr) }\end{array}$ \\
\hline $\mathrm{H}^{3}$ & $3.8 \mathrm{E}-11$ & $2.2 \mathrm{E}-02$ \\
\hline $\mathrm{Co}^{60}$ & $3.8 \mathrm{E}-15$ & $2.2 \mathrm{E}-06$ \\
\hline $\mathrm{Kr}^{85}$ & $1.7 \mathrm{E}-07$ & $1.0 \mathrm{E}+02$ \\
\hline $\mathrm{Sr}^{90}$ & $8.6 \mathrm{E}-14$ & $5.0 \mathrm{E}-05$ \\
\hline $\mathrm{Ru}^{106}$ & $1.9 \mathrm{E}-14$ & $1.1 \mathrm{E}-05$ \\
\hline $\mathrm{Cs}^{135}$ & $4.1 \mathrm{E}-13$ & $2.4 \mathrm{E}-04$ \\
\hline $\mathrm{Pu}^{238}$ & $4.0 \mathrm{E}-15$ & $2.3 \mathrm{E}-06$ \\
\hline $\mathrm{Pu}^{2397240}$ & $2.6 \mathrm{E}-14$ & $1.5 \mathrm{E}-05$ \\
\hline $\mathrm{Am}^{241}$ & $9.7 \mathrm{E}-15$ & $5.6 \mathrm{E}-06$ \\
\hline $\mathrm{Pu}^{241}$ & $3.6 \mathrm{E}-13$ & $2.1 \mathrm{E}-04$ \\
\hline & & $1.0 \mathrm{E}+02$ \\
\hline
\end{tabular}

${ }^{a}$ Concentration determined by dividing projected annual emissions column entries by total annual flow capacity, or $5.8 \mathrm{E}+14 \mathrm{ml} / \mathrm{yr}$.

Calculations for the flowrate and projected annual emission (with the exception of tritium) are as follows:

Annual Flowrate:

(60 minute/hour) $\left(8,760\right.$ hours/year) $\left(39,035 \mathrm{ft}^{3} / \text { minute }\right)^{1}$

$\left(28.32 \mathrm{~L} / \mathrm{ft}^{3}\right)(1,000 \mathrm{~mL} / \mathrm{L})=5.8 \mathrm{E}+14 \mathrm{~mL} /$ year.

Expected Annual Emission:

(concentration $\mu \mathrm{Ci} / \mathrm{mL})(1 \mathrm{E}-06 \mathrm{Ci} / \mu \mathrm{ci})(5.8 \mathrm{E}+14 \mathrm{~mL} /$ year) $=\mathrm{Ci} /$ year.

The projected emission of krypton is estimated based on the inventory inside the canisters that will be released on opening the canisters, (discussed in Section 7.1.7). All krypton-85 is assumed to be released. Gaseous tritium release is discussed as follows, based on evaporation of tritiated water from the basin pool.

The projected annual emission for tritium was calculated by multiplying the concentration of tritium in the basin water by the evaporation rate of the basin water to yield the amount of tritium released:

1 The maximum measured flow rate is used in projecting emissions. This is the same value that is used in reporting actual facility emissions. 
Concentration of tritium in basin water $(10 / 1 / 96)=5.98 \mathrm{E}-05 \mu \mathrm{Cj} / \mathrm{mL}$

Evaporation rate of basin water $=41.15 \mathrm{~L} / \mathrm{hr}$

$(5.98 \mathrm{E}-05 \mu \mathrm{Ci} / \mathrm{mL})(4.16 \mathrm{E}+04 \mathrm{~mL} / \mathrm{hr})(8,760 \mathrm{hr} /$ year $)(1 \mathrm{E}-06 \mathrm{Ci} / 1 \mu \mathrm{Ci})=$ $0.022 \mathrm{Ci} /$ year of ${ }^{3} \mathrm{H}$.

The above water activities can be considered as three general cases.

(1) Construction activities involve structural and piping reconfigurations to the building not unlike those activities that have been performed during previous piping reconfigurations, pipe cleaning, and discharge chute door installation. Historicaliy, there have been no well defined tangible effects from these activities on emission measurement data, provided controls such as those proposed in Chapter 8.0 are employed. Because most of the construction activities will occur before operations, which involve handling the fuel underwater (wit:h associated effects on projected air emissions), the emission est imate should bound the construction activity emissions.

(2) Operational activities during fut 1 removal activities above water largely involve movement of fuel canisters with the hoist/trolley system and transport of the MCO/casks. Fuel and empty canister movements have been conducted in the basin at a rate comparable to that required for fuel removal. There also have been cask transports made that had more cortaminated surface area than the MCO/cask will involve. None of these activities have shown a tangible effect on emission measurement data. Therefore, the above water operational activities are expected to be conducted within the emission estimate provided.

(3) Maintenance activities are expected to be similar to those routinely conducted in the basin. If the activities are conducted with controls described in Chapter 8.(1), the emissions from these activities also are expected to he covered by the emission estimate provided.

As noted in Section 6.1.3.3, the tanker truck that will transport treated basin water to the 200 Area ETF could constitute a point of emission separate from the 105-KW Basin. An emission estimate is provided in Table 10-4 based on the release of basin water using a relecise factor of 1.0 E-04 for the free fall of solutions in static air. Emission estimates in Table 10-4 are extremely conservative for the following reasons.

- The radionuclides in the basin water were assumed to be unchanged from those in Table 7-2. No credit is taken for decontamination provided by the IWTS.

- The release was assumed to occur from free falling water into an open or unconfined airspace. No credit was taken for the fact that the 
water is confined within the tanker truck with only a small

(approximately 12 inches) opening to the air.

4 To verify low emissions from the filled truck, the means of performing

6 sampling/measurement of the vent airstream. Alternatively, the vented air

7 from the tanker truck will be piped back to the basin. 
1 Table 10-4. Potential to Emit from Excess Water via Tanker Truck to 200 Area Effluent Treatment Facility. 2

3 Volume per truck load 5,000 gallons

4 Truck loads per year 12

5 Total annual volume 60,000 gallons $(227,124$ 1iters $)$ or $(227,124,000$ milliliters $)$

\begin{tabular}{|c|c|c|c|c|c|c|c|}
\hline 6 & Isotope & $\begin{array}{c}\text { Concentration } \\
\mu \mathrm{C} i / \mathrm{ml}\end{array}$ & $\begin{array}{c}\text { Total } \\
\text { quantity } \\
\text { Ci/yr }\end{array}$ & $\begin{array}{l}\text { Release } \\
\text { factor }\end{array}$ & $\begin{array}{l}\text { Unabated } \\
\text { release, } \mathrm{Ci} / \mathrm{yr}\end{array}$ & $\begin{array}{c}\text { CAP } 88 \text { dose } \\
\text { factors, mrem/Ci }\end{array}$ & $\begin{array}{c}\text { Unabated } \\
\text { dose, mrem/yr }\end{array}$ \\
\hline 7 & $\mathrm{Am}^{241}$ & 2.08 E-08 & 4.72 E-06 & $1.0 \mathrm{E}-04$ & $4.72 \mathrm{E}-10$ & $1.940 \mathrm{E}+01$ & $9.16 \mathrm{E}-09$ \\
\hline 8 & $\mathrm{Cs}^{134}$ & 2.00 E- 07 & 4.54 E-05 & $1.0 \mathrm{E}-04$ & $4.54 \mathrm{E}-09$ & $4.620 \mathrm{E}-02$ & $2.10 \mathrm{E}-10$ \\
\hline 9 & $\mathrm{Cs}^{137}$ & 1.35 E-04 & 3.07 E-02 & $1.0 \mathrm{E}-04$ & 3.07 E-06 & $3.530 \mathrm{E}-02$ & $1.08 \quad E-07$ \\
\hline 10 & $\mathrm{Co}^{60}$ & $3.89 \mathrm{E}-08$ & 8.84 E-06 & 1.0 E-04 & 8.84 E-10 & $4.280 \mathrm{E}-02$ & $3.78 \mathrm{E}-11$ \\
\hline 11 & $\mathrm{Eu}^{152}$ & 1.92 E-07 & 4.36 E-05 & $1.0 \mathrm{E}-04$ & 4.36 E-09 & $2.270 \mathrm{E}-02$ & $9.90 \mathrm{E}-11$ \\
\hline 12 & $E u^{154}$ & $1.20 \quad E-07$ & 2.73 E-05 & $1.0 \mathrm{E}-04$ & $2.73 \mathrm{E}-09$ & 2.690 E-02 & 7.33 E-11 \\
\hline 13 & $E u^{155}$ & 4.42 E-07 & $1.00 \mathrm{E}-04$ & $1.0 \mathrm{E}-04$ & $1.00 \mathrm{E}-08$ & 4.900 E-03 & $4.92 \mathrm{E}-11$ \\
\hline 14 & $\mathrm{Pu}^{238}$ & $1.57 \mathrm{E}-08$ & $3.57 \mathrm{E}-06$ & 1.0 E-04 & $3.57 \mathrm{E}-10$ & $1.180 E+01$ & $4.21 \quad E-09$ \\
\hline 15 & $\mathrm{Pu}^{239 / 240}$ & 1.57 E-08 & $3.57 \mathrm{E}-06$ & $1.0 \mathrm{E}-04$ & $3.57 \mathrm{c}-10$ & $1.280 \varepsilon+01$ & $4.56 \mathrm{E}-09$ \\
\hline 16 & $S r^{90}$ & $9.45 \mathrm{E}-06$ & 2.15 E-03 & $1.0 E-04$ & $2.15 \mathrm{E}-07$ & $6.450 \mathrm{E}-02$ & 1.38 E-08 \\
\hline 17 & $\mathrm{H}^{3}$ & $5.87 \quad E-05$ & $1.33 \mathrm{E}-02$ & 1.0 E-04 & $1.33 \mathrm{E}-06$ & 3.360 E-05 & $4.48 \mathrm{E}-11$ \\
\hline 18[ & Total & & 4.64 E-02 & & & & $1.41 \mathrm{E}-07$ \\
\hline
\end{tabular}

Concentration, $\mu C i / m 1$ : from Table 7-2.

Total quantity in $\mathrm{Ci} / \mathrm{yr}$ : from total annual volume $\times 1.0$ E-06.

Release factor from: PNL 1981.

$\mu \mathrm{Ci} / \mathrm{mL} \quad=$ microcuries per milliliter.

$\mathrm{Ci} / \mathrm{yr} \quad=$ curies per year.

mrem $/ \mathrm{Ci} \quad=$ millirem per curie.

mrem/yr $=$ millirem per year. 


\subsection{OFFSITE IMPACT (Requirement 14 and 15)}

The total effective dose equivalent for unabated potential emissions to the maximally exposed individual (MEI) is presented in Table 11-1. The MEI is located 6.14 miles west of the 100 Areas. The dose conversion factors used were derived from the EPA-approved CAP-88 code (EPA 1990). The projected dose for each individual radionuclide was calculated by multiplying the projected annual emission (Chapter 10.0, Table 10-3) by the dose conversion factor. The resulting dose is $2.8 \mathrm{E}-03$ millirem.

The TEDE to the MEI using good engineering judgment of projected abated emissions is presented in Table 11-2. The MEI is located 6.14 miles west of the 100 Areas. The dose conversion factors used were derived from the CAP-88 code. The projected dose for each individual radionuclide is calculated by multiplying the projected annual emission from Table 10-1 by the dose conversion factor. The resulting dose is $1.3 \mathrm{E}-03$ millirem.

Table 11-1. Total Effective Dose Equivalent to the Maximally Exposed Individual for the Unabated Emissions.

\begin{tabular}{|c|c|c|c|c|}
\hline Radionuclide & $\begin{array}{l}\text { Actual } \\
\text { emissions } \\
(\mathrm{Cj} / \mathrm{yr}) \\
\end{array}$ & $\begin{array}{c}\text { CAP }-88 \text { Dose } \\
\text { conversion factor, } \\
\text { mrem } / \mathrm{Ci}\end{array}$ & $\begin{array}{l}\text { TEDE to } \\
\text { the MEI, } \\
\text { mrem } / y r\end{array}$ & $\begin{array}{c}\text { Dose } \\
\text { (percent of } \\
\text { total) }\end{array}$ \\
\hline $\begin{array}{l}\mathrm{Co}^{60} \\
\mathrm{Sr}^{90} \\
\mathrm{Ru}^{106} \\
\mathrm{Sb}^{125} \\
\mathrm{Cs} \\
\mathrm{Cs} s^{137} \\
\mathrm{Eu}^{154} \\
\mathrm{Eu}^{155} \\
\mathrm{Pu}^{238} \\
\mathrm{Pu}^{239 / 240 \quad b} \\
\mathrm{Pu}^{241} \mathrm{~b} \\
\mathrm{Am}^{241 \quad \mathrm{~b}}\end{array}$ & $\begin{array}{ll}1.4 & E-05 \\
4.4 & E-05 \\
8.1 & E-05 \\
1.9 & E-05 \\
3.4 & E-06 \\
1.8 & E-03 \\
4.3 & E-05 \\
8.9 & E-06 \\
1.7 & E-05 \\
1.1 & E-04 \\
1.6 & E-03 \\
4.1 & E-05\end{array}$ & $\begin{array}{ll}4.28 & \mathrm{E}-02 \\
6.45 & \mathrm{E}-02 \\
3.08 & \mathrm{E}-02 \\
6.13 & \mathrm{E}-03 \\
4.62 & \mathrm{E}-02 \\
3.53 & \mathrm{E}-02 \\
2.69 & \mathrm{E}-02 \\
4.90 & \mathrm{E}-03 \\
1.18 & \mathrm{E}+01 \\
1.28 & \mathrm{E}+01 \\
2.03 & \mathrm{E}-01 \\
1.94 & \mathrm{E}+01\end{array}$ & $\begin{array}{ll}6.02 & \mathrm{E}-07 \\
2.82 & \mathrm{E}-06 \\
2.51 & \mathrm{E}-06 \\
1.13 & \mathrm{E}-07 \\
1.57 & \mathrm{E}-07 \\
6.27 & \mathrm{E}-05 \\
1.15 & \mathrm{E}-06 \\
2.42 & \mathrm{E}-08 \\
2.01 & \mathrm{E}-04 \\
1.42 & \mathrm{E}-03 \\
3.15 & \mathrm{E}-04 \\
8.04 & \mathrm{E}-04\end{array}$ & $\begin{array}{r}<1.0 \\
<1.0 \\
<1.0 \\
<1.0 \\
<1.0 \\
2.2 \\
<1.0 \\
<1.0 \\
7.1 \\
50.5 \\
11.2 \\
28.6\end{array}$ \\
\hline Total & $3.7 \mathrm{E}-03$ & & $2.81 \mathrm{E}-03$ & 100.0 \\
\hline
\end{tabular}

a Column might not add up to $100 \%$ due to rounding off.

b Radionuclides that could contribute greater than $10 \%$ of the potential to emit.

$\mathrm{Ci} / \mathrm{yr}=$ curie per year .

MEI = maximaliy exposed individual.

$\mathrm{mrem} / \mathrm{Ci}=$ millirem per curie.

$\mathrm{mrem} / \mathrm{yr}=$ millirem per year .

$T E D E$ = total effective dose equivalent. 
Table 11-2. Total Effective Dose Equivalent to the Maximally Exposed Individual Using CAP-88 Dose Conversion Factors for Good Engineering Judgment of Abated Emissions.

\begin{tabular}{|c|c|c|c|c|}
\hline Radionuclide & $\begin{array}{c}\text { Projected } \\
\text { emissions } \\
(\mathrm{Ci} / \mathrm{yr})\end{array}$ & $\begin{array}{l}\text { CAP-88 Dise } \\
\text { conversion } \\
\text { factor } \\
\text { mrem } / \mathrm{C}\end{array}$ & $\begin{array}{l}\text { TEDE to } \\
\text { the MEI, } \\
\text { mrem } / y r\end{array}$ & $\begin{array}{c}\text { Dose, percent } \\
\text { of total }{ }^{\mathrm{a}}\end{array}$ \\
\hline $\mathrm{Co}^{60}$ & $1.2 \mathrm{E}-05$ & $4.28 E-102$ & $5.3 \quad E-07$ & $<1$ \\
\hline$k r^{85}$ & $1.0 \mathrm{E}+02$ & 7.49 E-08 & 7.49 E-06 & $<1$ \\
\hline$S r^{90}$ & $6.2 \mathrm{E}-04$ & $6.45 \mathrm{E}-112$ & $4.0 \quad E-05$ & 3.1 \\
\hline $\mathrm{Ru}^{106}$ & $2.7 \mathrm{E}-05$ & $3.08 \mathrm{E}-(1)$ & $8.3 \quad E-07$ & $<1$ \\
\hline $\mathrm{Cs}^{137}$ & 5.3 E-04 & $3.53 \mathrm{E}-(12$ & $1.9 \quad E-05$ & 1.5 \\
\hline $\mathrm{Pu}^{238}$ & 5.7 E-06 & $1.18 \mathrm{E}+(1)$ & $6.7 \quad E-05$ & 5.3 \\
\hline$P u^{239 / 240 ~ b}$ & 3.4 E-05 & $1.28 E+(1) 1$ & $4.4 \quad E-04$ & 35.0 \\
\hline $\mathrm{Pu}^{241 \mathrm{~b}}$ & $1.2 \mathrm{E}-03$ & $2.03 \mathrm{E}-(11$ & $2.3 \quad E-04$ & 18.5 \\
\hline $\mathrm{Am}^{241 \mathrm{~b}}$ & $2.4 E-05$ & $1.94 E+(1) 1$ & $4.6 \quad E-04$ & 36.6 \\
\hline Total & $1.0 \mathrm{E}+02$ & & $1.3 \mathrm{E}-03$. & 100 \\
\hline
\end{tabular}

Column might not add up to $100 \%$ due to rounding off.

b Radionuclides that could contribute greater than $10 \%$ of the potential to emit.

$\mathrm{Ci} / \mathrm{yr}=$ curie per year .

MEI = maximaliy exposed individual.

mrem $/ \mathrm{Ci}=$ millirem per curie.

mrem $/ y r=$ millirem per year.

TEDE = total effective dose equivalent. 


\subsection{FACILITY LIFETIME (Requirement 17)}

The activities described in this NOC are scheduled to begin in calendar 5 year 1997 and will continue over an approximate 2-year period. The date for 6 basin deactivation has not been established and depends on milestones

7 established in the Hanford Federal Facility Agreement and Consent Order 8 (Ecology et a1. 1996). 
DOE/RL-97-28, Rev. 0

04/97

1
2
3
4
5

This page intentionally left blank. 


\subsection{TECHNOLOGY STANDARDS (Requirement 18)}

Reconfigurations to emission control process equipment (water treatment) are proposed. The IWTS will be designed and constructed to meet ANSI/ANS-57.7 (ANS 1988), Section 6.3, except that 10 CFR 50 is not applicable.

During the other activities described in this NOC, good engineering practices will be employed to reduce airborne emissions. General design criteria are based on "National Consensus" codes and standards and pertinent state and local codes and standards will be used. 
This page intentionally left blank. 


\subsection{REFERENCES}

ANS, 1988; "Design Criteria for an Independent Spent Fuel Storage Installation (Water Pool Type)", ANS 57-7-1988, American Nuclear Society, LaGrange, Illinois.

DOE/RL-93-13, Notice of Construction for the 105-KE Encapsulation, U.S. Department of Energy, Richland Operations Office, Richland, Washington.

DOE/RL-95-65, Radioactive Air Emissions Notice of Construction, Debris Removal, $105 \mathrm{KE}-$ Basin, U.S. Department of Energy, Richland Operations Office, Richland, Washington.

DOE/RL-96-37, Radionuclide Air Emissions Report for the Hanford Site Calendar Year 1995, U.S. Department of Energy, Richland Operations Office, Richland, Washington.

DOE/RL-96-76, U.S. Environmental Protection Agency.Clean Air Act Notice of Construction for Spent Nuclear Fuel Project--Hot Conditioning System Annex, Project W-484, U.S. Department of Energy, Richland Operations Office, Richland, Washington.

DOE/RL-96-101, Radioactive Air Emissions Notice of Construction Fuel Removal for 105-KE Basin, U.S. Department of Energy, Richland Operations Office, Richl and, Washington.

Ecology, EPA, and DOE-RL, 1996, Hanford Federal Facility Agreement and Consent Order, Washington State Department of Ecology, U.S. Environmental Protection Agency, U.S. Department of Energy, Richland Operations Office, 01 ympia, Washington, amended periodically.

EPA, 1990, The Clean Air Act Assessment Package - 1988 (CAP-88), A Dose and Risk Assessment Methodology for Radionuclide Emissions to Air, Vols. 1-3, U.S. Environmenta7 Protection Agency, Washington, D.C.

HNF, 1997a, Analysis of Water from $K$ West Basin Canisters (Second Campaign), HNF-SD-SNF-TI-048, Rev. 0, Duke Engineering \& Services Hanford, Inc., Richland, Washington.

HNF, 1997b, Cesium-137 in $K$ West Basin Canister Water, HNF-SD-SNF-ANAL-014, Rev. 0, Duke Engineering \& Services Hanford, Inc., Richland, Washington.

HNF, 1997c, Performance Specification for Design, Fabrication, Testing, and Technical Assistance for the $K$ West Basin Water Treatment System, HNF-S-0564, Rev. O, Duke Engineering \& Services Hanford, Inc., Richland, Washington.

PNL, 1981, Aerosols Generated by Free Fall Spills of Powders and Solutions in Static Air, PNL-3786, Pacific Northwest Laboratory, Richland, Washington 
WDOH, 1993, letter from A.W. Conklin, Washington State Department of Health, to J.D. Bauer, U.S. Department of Energy, Richland Field Office, September 13, 1993, AIR 93-908.

WDOH, 1996, letter from A.W. Conklin, Washington State Department of Health, to J.E. Rasmussen, U.S. Department of Energy, Richland Operations Office, September 11, 1996, AIR 96-906.

WHC, 1993a, BARCT Assessment for 105-KE Encapsulation Activity, WHC-SD-NR-TI-052, Westinghouse Hanford Company, Richland, Washington.

WHC, 1993b, Test Report - 100K Basin Air Flow Effluent Volume Test, WHC-SD-NR-TRP-015, Westinghouse Hanfond Company, Richland, Washington.

WHC, 1993c, Transport Mechanism of Radionuclides in 105-KE Fuel Storage Basin to Airborne Effluent Release, WHC-SD-IYR-ES-016, April 1993, Westinghouse Hanford Company, Richland, Washington.

WHC, 1995a, 105-K Basin Material Design Basis Feed Description for Spent Nuclear Fuel Project Facilities, WHC-SD-SNF-TI-009, Rev. 0, Westinghouse Hanford Company, Richland, Washington.

WHC, 1995b, The K-Basin Corrosion Program Report, WHC-EP-0877, Rev. 0, September 1995, Westinghouse Hanford Dompany, Richland, Washington.

WHC, 1995c, Observations During First $K$ West Fuel Shipping Campaign, WHC-SD-SNF-ER-010, Rev. 0, Westinghouse Hanford Company, Richl and, Washington.

WHC, 1996a, Data Analysis, K West Basin Canister Liquid and Gas Samples, Gamma Energy Analysis and Mass Spectrometry Data, WHC-SD-SNF-ANAL-007, Rev. 0, Westinghouse Hanford Company, Richland, Washington.

WHC, 1996b, K Basins Safety Analysis Report, WHC-SD-WM-SAR-062, Rev. 3, Westinghouse Hanford Company, Richland, Washington.

WHC, 1996c, SARP (Safety Analysis Report Pickaging) for the MCO Transport, WHC-SD-TP-SARP-017, Draft, Rev. 0, Wesitinghouse Hanford Company, Richl and, Washington. 


\section{APPENDIX A \\ DISCUSSION OF AS LOW AS REASONABLY ACHIEVABLE CONTROL TECHNOLOGY}

As stated in WAC 246-247-040(4), "All existing emission units and nonsignificant reconfigurations shali utilize ALARACT..." By definition, the proposed reconfiguration is "nonsignificant". As stated in WAC 246-247-030(6), in part, "Control technology that meets BARCT requirements a1 so meets ALARACT requirements."

$A$ best available radionuclide control technology (BARCT) assessment (WHC 1993a) was prepared for the 105-KE Basin encapsulation activity (DOE/RL-93-13). The BARCT assessment studied the economic impacts of installing several HEPA filtration systems in the 105-KE Basin. The BARCT assessment revealed that installing HEPA filtration on the 105-KE Basin was not cost effective.

In a September 13, 1993 Tetter to U.S. Department of Energy, Richland Operations Office, the WDOH agreed (subject to specific conditions) that the water in the K-Basins would be accepted as BARCT for the control of airborne radionuclides (WDOH 1993). 
This page intentionally left blank. 


\section{DISTRIBUTION}

OFFSITE

A. W. Conklin, Head

Air Emissions and Defense Waste Section

Division of Radiation Protection

State of Washington Department of Health

Airdustrial Park Building 5, LE-13

Olympia, Washington 98504-0095

S. E. Mckinney

Hanford Project Manager

Washington State Department of Ecology

P. 0 . Box 47600

Olympia, Washington 98504-7600

S. M. ATexander

Perimeter Section

Washington State Department of Ecology

1315 West Fourth Avenue

Kennewick, Washington 99336-6018

A. J. Franke1, Acting Director

Air and Toxics Division

U.S. Environmental Protection Agency

Region 10

Mail Stop AT-082

1200 Sixth Avenue

Seattle, Washington 98101

J. Wilkinson

Confederated Tribes of the Umatilia

Indian Reservation

P. 0. Box 638

Pendleton, Oregon 97801

D. Powaukee

Nez Perce Tribe

P. 0 . Box 305

Lapwai, Idaho 80540

R. Jim, Manager

Environmental Restoration/ Waste Management Program

Confederated Tribes and Bands of the Yakama Nation

P. 0. Box 151

Toppenish, Washington 98948 
G. M. Bell

J. M. Escamillo

R. G. Holt

R. L. Long

P. G. Loscoe

E. D. MacATister

H. M. Rodriguez (7)

S7-41

K. M. Schierman

S7-41

E. E. Sellers

A5-15

Reading Room

Duke Engineering \& Services Hanford, Inc.

K. E. Ard

D. C. Best

B. S. Carlisle

J. B. Crystal

C. Defigh-Price

R. G. Gant (3)

M. W. Gmyrek

J. R. Gregory

F. G. Hudson

G. S. Hunacek

P. G. Huntley

P. G. LeRoy

R. J. Lodwick

J. P. Matthews

C. T. Miller

D. W. Siddoway

J. A. Swenson

D. S. Takasumi

C. A. Thompson

D. J. Watson (3)

PGL File/LB

SNF Project Files

Fluor Daniel Hanford, Inc.

J. A. Bates

H6-36

J. D. Davis

H5-20

E. W. Gerber

R3-11

J. L. Jacobson

B3-70

K. A. Peterson

H6-36

L. K. Trent

H8-67

N. H. Williams

R3-11

B. D. Williamson

B3-15 


\section{DISTRIBUTION (cont)}

ONSITE

MSIN

Hanford Technical Library

K1-11

Numatec Hanford Corporation

G. P. Chevrier

R3-86

Rust Federal Services of Hanford Inc.

E. M. Greager

H6-36

L. D. Kamberg

H6-26

J. J. Luke

Air Operating Permit File

H6-25

H6-25

Lockheed Martin Services, Inc.

Central Files

A3-88

DPC

H6-08

EDMC (2)

H6-08 


\section{DOE/RL-97-28, Rev. 0}

$04 / 97$

This page intentionally left blank. 